Intl. J. River Basin Management Vol. 5, No. 4 (2007), pp. 329-346

(C) 2007 IAHR, INBO \& IAHS

\title{
Revised equations for Manning's coefficient for sand-bed rivers
}

\author{
AMINUDDIN AB. GHANI, Deputy Director, River Engineering and Urban Drainage Research Centre (REDAC), \\ Universiti Sains Malaysia, Engineering Campus, Seri Ampangan, 14300 Nibong Tebal, Penang, Malaysia, \\ E-mail: redac02@eng.usm.my
}

NOR AZAZI ZAKARIA, Director, REDAC, Universiti Sains Malaysia, Engineering Campus, Seri Ampangan, 14300 Nibong Tebal, Penang, Malaysia. E-mail: redac01@eng.usm.my

CHANG CHUN KIAT, Science Officer, REDAC, Universiti Sains Malaysia, Engineering Campus, Seri Ampangan, 14300 Nibong Tebal, Penang, Malaysia.E-mail: redac10@eng.usm.my

JUNAIDAH ARIFFIN, Deputy Dean, Faculty of Civil Engineering, Universiti Teknologi MARA, 40450 Shah Alam, Malaysia

ZORKEFLEE ABU HASAN, Senior Lecturer, REDAC, Universiti Sains Malaysia, Engineering Campus, Seri Ampangan, 14300 Nibong Tebal, Penang, Malaysia.E-mail: redac04@eng.usm.my

AHMAD BAKRI ABDUL GHAFFAR, Postgraduate Student, REDAC, Universiti Sains Malaysia, Engineering Campus, Seri Ampangan, 14300 Nibong Tebal, Penang, Malaysia.E-mail: redac09@eng.usm.my

\begin{abstract}
The procedure for selecting values of Manning $n$ is subjective and requires judgment and skill which are developed primarily through experience. Government agencies and private sectors in developed nations such as the USA are still doing research on predicting $n$ values for rivers. Since flow and boundary roughness vary with river conditions, such research is therefore pertinent for rivers in Malaysia where floods are one of primary concerns. Research on Manning $n$ value was started by River Engineering and Urban Drainage Research Centre (REDAC), Universiti Sains Malaysia (USM) since 2000 at the Kinta River catchment. Further data collections were later made at two other major rivers i.e. Langat River and Kulim River. Two new equations are proposed for determining Manning $n$ for sand-bed rivers in Malaysia based on 163 data collected from these three rivers. On average, both equations have an error less than $10 \%$ in predicting flow discharge for all 163 data.
\end{abstract}

Keywords: Flood mitigation; sand-bed rivers; flow resistance; Manning $n$.

\section{Introduction}

Southeast Asia has long experienced a monsoon climate with dry and wet seasons. With mean annual rainfall precipitation locally in excess of $5,000 \mathrm{~mm}$, the very intense rainstorms in the steep mountains of Malaysia have caused frequent and devastating floods in the last five years especially in 2003 (Northern states of Kedah, Penang and Perlis) and 2006 (Southern states of Malacca, Johor and Pahang). Urbanization also exacerbates the problem and increases river discharge due to increase in impervious areas of the upper watershed.

The protection of the communities against floods has become the primary concern of the Malaysian government. One of the methods commonly used to mitigate the floods is by constructing levees or bunds along the lowland areas surrounding river channel. A recent example of the flood mitigation project involves the Muda River, Kedah (Julien et al. 2006) that highlights several important points in the design of flood remediation countermeasures against intense and regular flooding during the monsoons of South-East Asia. The study reach covers $41.2 \mathrm{~km}$ between the river mouth and Ladang Victoria (Figure 1) which was the area that was heavily flooded in 2003. The hydraulic analysis using HEC-RAS model of the existing river system in the study area was carried out to provide information on the variations of river water levels, discharges, and velocities during flood events. Due to lack of field measurement data to determine suitable values of Manning $n$, different values were tried during the calibration of the HEC-RAS model. The best results were obtained with Manning $n$ of 0.030 and 0.050 for the main channel and floodplains respectively (Figure 2). Water level records at three locations (Ladang Victoria, Bumbong Lima and River Mouth) during the 2003 flood were used to check the predicted water level by the HEC-RAS model. The model results are considered sufficiently accurate for the determination of levee heights. This study by

Received on October 9, 2006. Accepted on April 18, 2007. 


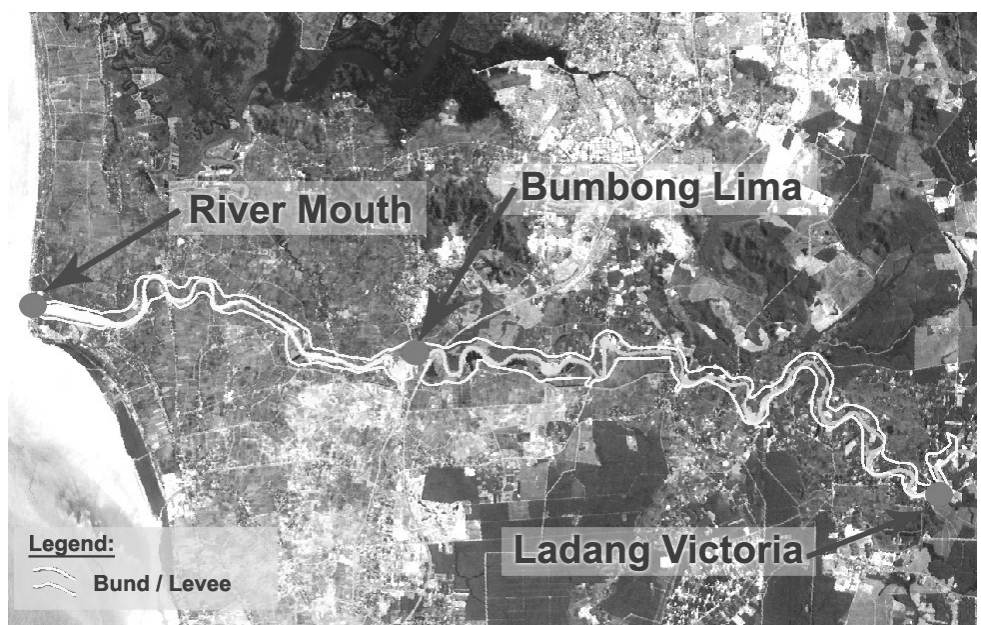

Figure 1 Flood mitigation for Muda River, Kedah.

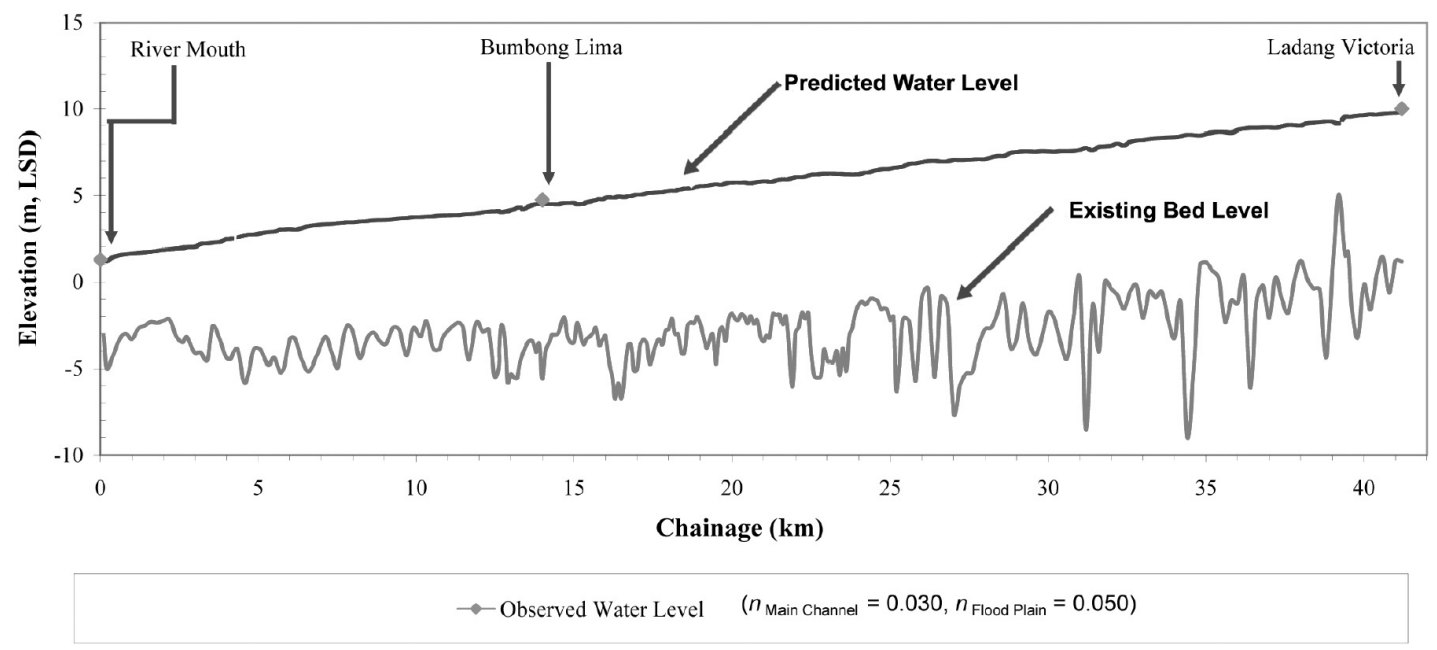

Figure 2 Hydraulic analysis using HEC-RAS for Muda River, Kedah.

Julien et al. (2006) highlights the need to accurately determine the suitable values of Manning $n$ for both the main channel and floodplain.

Most hydraulic computations related to indirect estimates of discharge require an evaluation of the roughness characteristics. A number of empirical equations were developed and these researches have been continued by government agencies and private sectors in the developed nation such as USA (Dooge 1991, Yen 2002). Natural channel morphology depends on the interaction between fluid flow and the erodible channel boundary. Velocity is strongly related to flow resistance, which is one of the most important elements in the interaction between the fluid flow and the channel boundary (Graf 1998, Yen 2002, Julien et al. 2002).

Engineers use a number of flow resistance techniques involving grain roughness, form roughness and a combination of both. The most common practice is to express the total resistance in terms of Manning $n$. As a consequence, Manning's equation has been widely used for predicting discharge in natural channels (Chow 1959, Barnes 1976, Raudkivi 1993, Karim 1995, Julien 2002). This paper summarizes the recent results in this field based on field data collected at three rivers in Malaysia i.e. Kinta, Langat and Kulim rivers (Abdul Ghaffar 2003, Ariffin 2004, Chang 2006).

\section{Existing equations for evaluation Manning's coefficient}

Manning $n$ is often assumed to be a constant that is independent of either flow discharge or depth. However, Chow (1959) indicates that the value of $n$ is highly variable and depends on a number of factors: (1) surface roughness - fine sediment size such as sand will result in a relatively low value of $n$ and coarse sediments such as gravels, in a high value of $n$; (2) vegetation - may also be regarded as a kind of surface roughness depending on the height, density, distribution and type of vegetation; (3) channel irregularity - comprises irregularities in wetted perimeter and variations in cross section, size and shape along the channel length. A gradual and uniform change in cross section, size and shape will not appreciably affect the value of $n$; (4) channel alignment - smooth curvature with large radius will give a relatively low value of $n ;(5)$ silting and scouring - silting may change a very irregular channel into a comparatively uniform one and decrease $n$, whereas scouring may do the reverse and increase $n ;(6)$ obstruction - the presence of log jams, bridge piers, and the like tends to increase $n$; (7) size and shape of channel - an increase in hydraulic radius may either increase or decrease $n$ depending on the condition of the channel; and (8) stage and discharge $-n$ value in most 
Table 1 Suggested Manning $n$ for natural streams (Chow, 1959).

\begin{tabular}{lccc}
\hline Type of channel and description & Minimum & Normal & Maximum \\
\hline Stream on plain & & & \\
Clean, straight, full stage, no rifts or deep pools & 0.025 & 0.030 & 0.033 \\
Same as above, but more stones and weeds & 0.030 & 0.035 & 0.040 \\
Clean, winding, some pools and shoals & 0.033 & 0.040 & 0.045 \\
Same as above, but more stones and weeds & 0.035 & 0.045 & 0.050 \\
Clean, winding, some pools and shoals, weeds & 0.045 & 0.050 & 0.060 \\
$\quad$ and more stones & & & \\
\hline
\end{tabular}

streams decreases with increase in stage and discharge. However, the $n$ value may be large at high stages if the banks are rough and grassy. Chow also gives suggested values of $n$ in a table where three values (minimum, normal, maximum) of $n$ are given for each kind of channel. Table 1 gives values of $n$ from Chow (1959) relevant to the present study.

Several available equations to predict values of $n$ for rivers can be found in Simons and Senturk (1992), Yang (1996) and Lang et al. (2004). These equations can be categorized as: (1) equations that are based on bed sediment size; (2) equations that are based on the ratio of flow depth or hydraulic radius over sediment size; and (3) equations that includes water-surface slope besides bed sediment size and hydraulic radius or flow depth. In the present study, seven equations were evaluated as follows:

\section{Category 1: Equations based on bed sediment size}

$$
\begin{aligned}
\text { Strickler (1923): } n & =\frac{1}{21.1} d_{50}^{1 / 6} \\
\text { Meyer-Peter \& Muller (1948): } n & =\frac{1}{26} d_{90}^{1 / 6} \\
\text { Lane \& Carlson (1953): } n & =\frac{1}{21.14} d_{75}^{1 / 6}
\end{aligned}
$$

Category 2: Equations based on ratio of $R$ or $y_{o}$ over sediment size

$$
\begin{aligned}
\text { Limerinos (1970): } n & =\frac{0.113 R^{1 / 6}}{0.35+2.0 \log _{10}\left(\frac{R}{d_{50}}\right)} \\
\text { Bray (1979): } n & =\frac{0.113 y_{o}^{1 / 6}}{1.09+2.2 \log _{10}\left(\frac{y_{o}}{d_{50}}\right)}
\end{aligned}
$$

Category 3: Equations based on $S_{o}$

$$
\begin{aligned}
\text { Brownlie (1983): } n= & {\left[1.893\left(\frac{R}{d_{50}}\right)^{0.1374} \times S^{0.1112}\right] } \\
& \times 0.034 \times\left(d_{50}\right)^{0.167} \\
\text { Bruschin (1985): } n= & \frac{d_{50}^{1 / 6}}{12.38} \times\left(\frac{R}{d_{50}} \times S_{o}\right)^{1 / 7.3}
\end{aligned}
$$

Herein, $d$ is the representative sediment size in meters $\left(d_{50}, d_{75}\right.$ or $\left.d_{90}\right), R$ the hydraulic radius in meters, $y_{o}$ the uniform flow depth in meters and $S_{o}$ the water-surface slope. Equations with category 1 were developed from data for large, wide rivers with low slopes. Bed material is the primary source of resistance (Rahmeyer, 2006). Limerinos (1970)'s equation was developed using 50 data from gravel-bed streams in California where $d_{50}$ ranges from 6 to $253 \mathrm{~mm}$. The river channels are relatively wide stream of simple trapezoidal shape that will contain the entire discharge without overflow (Lang et al. 2004). Bray (1979)'s equation was calibrated to data from 67 gravel-bed reaches in Alberta, Canada where $d_{50}$ ranges from 18 to $147 \mathrm{~mm}$ and channel width is between 14 to $546 \mathrm{~m}$ (Lang et al. 2004). Equations by Brownlie (1983) and Bruschin (1985) were based mainly on flume and sandy river data (Raudkivi, 1993).

\section{Study sites}

The data collection programme for the present study was implemented at three major rivers (Figure 3) in Malaysia from 2000 until 2006. Initially the study was carried out at Kinta River in 2000 (Abdul Ghaffar, 2003). The second study was done at Langat River from 2000 until 2002 (Ariffin, 2004). The third study was later completed at Kulim River in 2006 (Chang, 2006). A short description of the three rivers is given herein including the present landuse and catchment size. Detailed hydraulic characteristics of the study sites are given in Section 4.

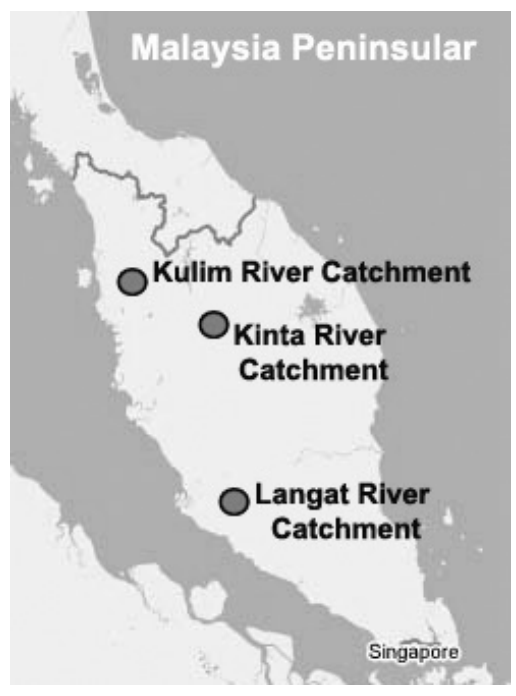

Figure 3 Locations of rivers for the present study. 


\section{Kinta River}

The Kinta River catchment (Figure 4) comprises the entire $2540 \mathrm{~km}^{2}$ of the Sungai Kinta in the central-eastern section of Perak State. The topography of the catchment consists of steep forest-covered mountains and hills in the north and east, progressively giving way to the expansive Kinta Valley to the south of Ipoh, most which lies between the $10 \mathrm{~m}$ and $50 \mathrm{~m}$ contour. Land use of the Kinta Valley consists of agriculture (e.g. Rubber,

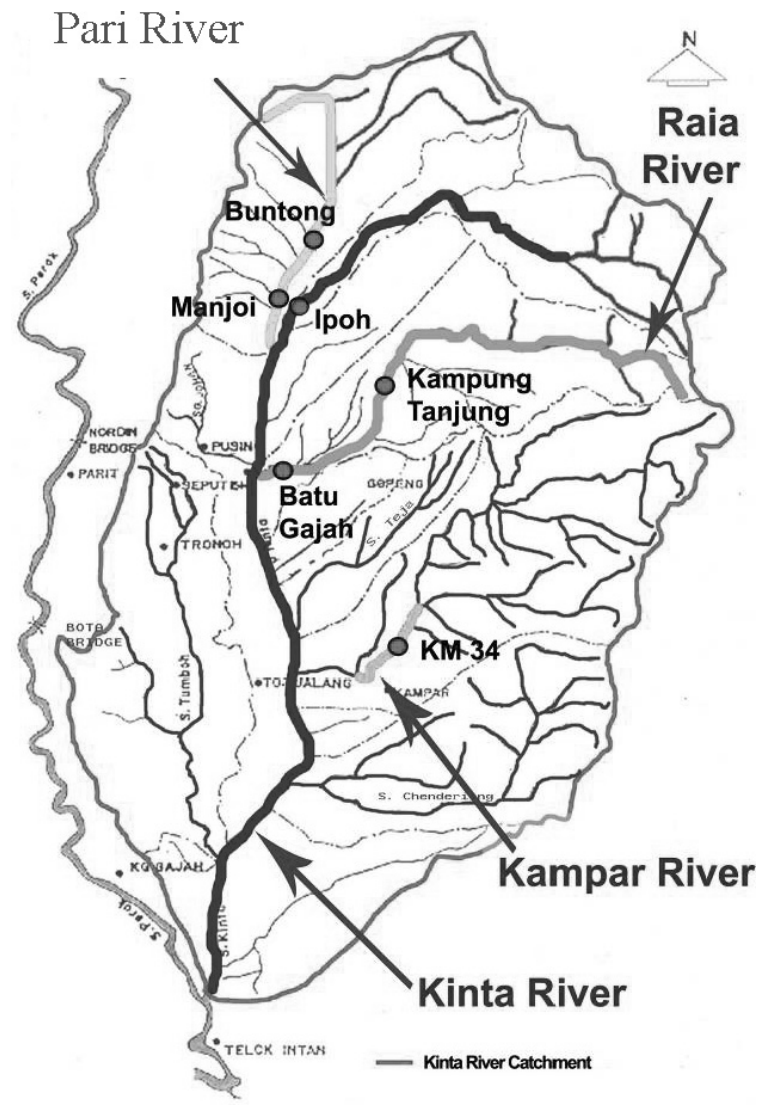

oil palm and fruit trees), urban development and unproductive ex-mining land including tailings and ponds.

The major tributary of Kinta River from the north-west is the Pari River $\left(245 \mathrm{~km}^{2}\right)$ which joints at Ipoh. Tributaries from the steeper eastern catchment include the Raia River $\left(250 \mathrm{~km}^{2}\right)$, Kampar River $\left(430 \mathrm{~km}^{2}\right)$ which joint at Tg Tualang. The study sites consist of four rivers (Figure 5), namely Kinta River, Raia River, Pari River and Kampar River, which are situated in Kinta River Catchment as depicted in Figure 4. Six study sites for this study were chosen based on the following criteria:

(a) Natural reach: undeveloped upper or middle reach (less than 30\% catchment development) - Kampar River @ KM 34 (Figure 5a).

(b) Natural reach: Developed middle reach (more than $30 \%$ development) - Raia River @ Kampung Tanjung (Figure 5b) and Batu Gajah (Figure 5c).

(c) Modified reach: Developed middle reach (more than $30 \%$ development) - Kinta River (Figure 5d), Pari River @ Manjoi (Figure 5e) and Buntong (Figure 5f).

\section{Langat River}

The two study sites studied are located in the Langat River basin (Figure 6) in Selangor. The tributaries Sungai Lui and Sungai Semenyih flow into the main river Sungai Langat. In both the upper and lower region along Sungai Lui and Sungai Semenyih there are scatter of rubber plantations and isolated villages. The Sungai Langat around Kajang area is densely populated judging from the vast amount of traffic volume. In contrast, the lower region of Sungai Langat has yet to be fully developed. There are rubber and oil palm plantations within the catchment. Some areas on both sides of the river banks under study are inaccessible as they are covered by thick bushes and shrubs.

Figure 4 Kinta River catchment.

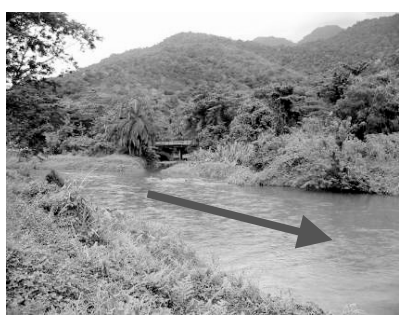

(a) Kampar River @ KM 34

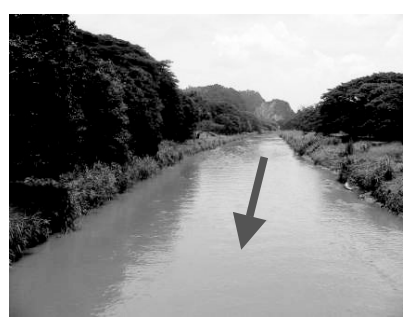

(d) Kinta River

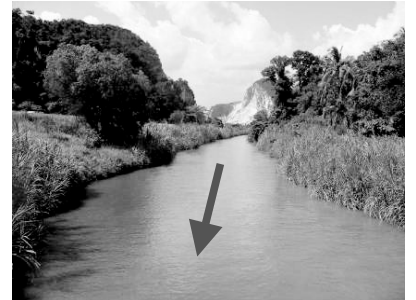

(b) Raia River @ Kampung Tanjung

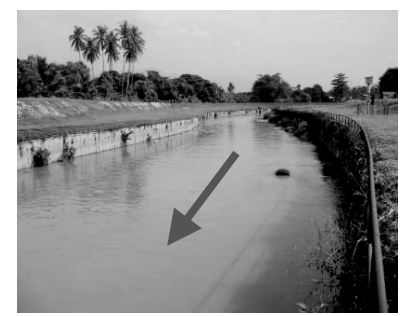

(e) Pari River @ Manjoi

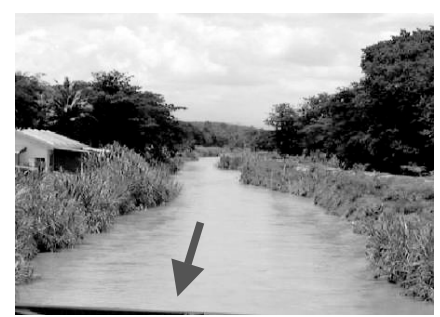

(c) Raia River @ Batu Gajah

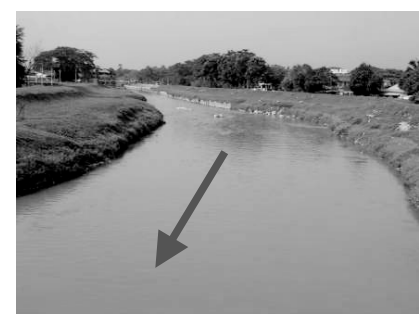

(f) Pari River @ Buntong

Figure 5 Study sites@ Kinta River catchment. 


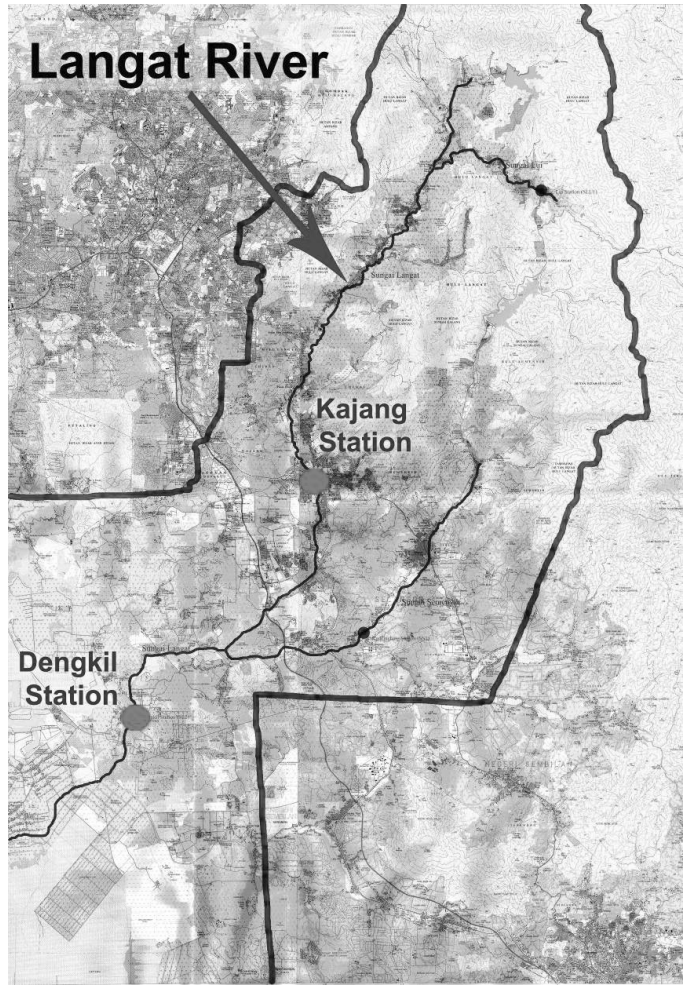

Figure 6 Langat River catchment.

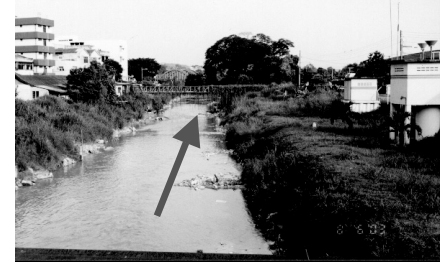

(a) Langat River @ Kajang

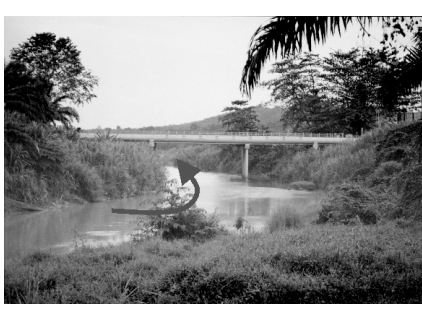

(b) Langat River @ Dengkil
Figure 7 Study sites @ Langat River catchment.

Measurements were made from two gauging stations namely Kajang and Dengkil along Sungai Langat with catchment size of $380 \mathrm{~km}^{2}$ and $1240 \mathrm{~km}^{2}$ respectively (Figure 7).

\section{Kulim River}

The study area is located at the southern part of the state of Kedah in the northwestern corner of Peninsular Malaysia (Figure 8). It lies within the district of Kulim and upstream of Seberang Perai in Penang. Kulim River catchment consists of 15 subcatchments, with the total catchment area of $130 \mathrm{~km}^{2}$. Kulim river tributaries include Tebuan River, Kilang Sago Monsoon Drain, Wang Pinang River, Keladi River and Klang Lama River drain the urban conurbation of Kulim extending from town to the north. Downstream of Kulim town, the catchment comprises mainly of rubber and oil palm estate located mainly at the confluences of Kulim River tributaries. The study reach covers about $14.39 \mathrm{~km}$ of Kulim River, from the upstream $(\mathrm{CH}$ 14390) to the state boundary between Kedah and Penang (CH 1900) and further downstream at the Ara Kuda gauging station ( $\mathrm{CH} 0)$. At the headwaters, the Kulim

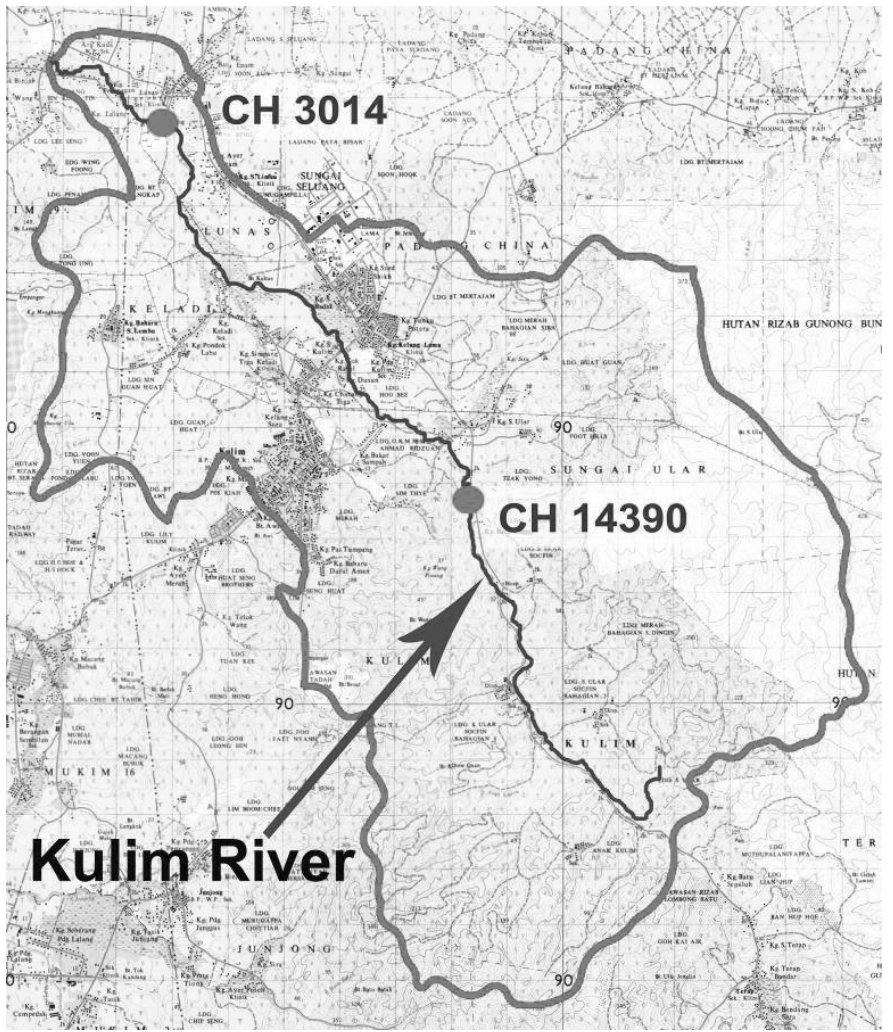

Figure 8 Kulim River catchment.

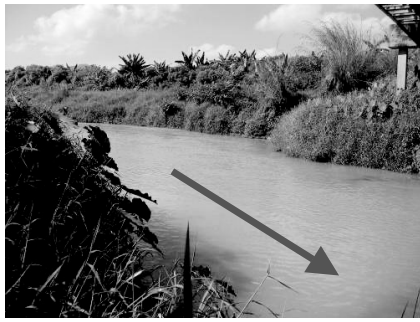

(a) Kulim River @ CH 14390

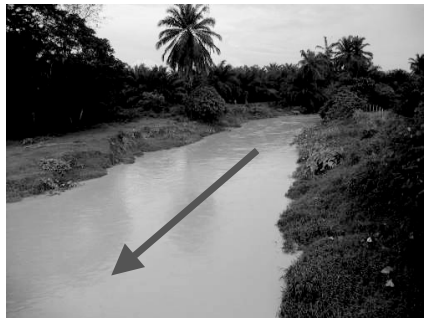

(b) Kulim River @3014
Figure 9 Study sites @ Kulim River catchment.

catchment is hilly and densely forested and Kulim River arises on the western slopes of Gunung Bongsu Range and flowing in a north-westerly direction, and joined Keladi River in the vicinity of Kulim town. The river slopes are steep and the channel elevation drops from $500 \mathrm{~m}$ to $20 \mathrm{~m}$ average mean sea level over a distance of $9 \mathrm{~km}$. The central area of the catchment is undulating with elevations ranging from $100 \mathrm{~m}$ down to $18 \mathrm{~m}$ average mean sea level. Two study sites are located at CH 14390 and CH 3014 (Figure 9).

\section{Field data collection}

Field measurements were obtained along selected cross sections of the study sites by using the Hydrological Procedure (DID, 1976, 1977) and recent manuals (Yuqian, 1989; USACE 1995, Edwards \& Glysson, 1999; FISRWG, 2001; Lagasse et al., 2001; Richardson et al., 2001). The data collection includes flow discharge, suspended load and bed load (Ab. Ghani et al., 2003). A total of 163 data sets were obtained with 122 data for Kinta River, 23 data for Langat River and 18 data for Kulim River. 
Table 2 Range of field data for Kinta River catchment (Ab. Ghani et al. 2003).

\begin{tabular}{|c|c|c|c|c|c|c|}
\hline Study site & $\begin{array}{c}\text { Kampar River } \\
\text { @ KM } 34\end{array}$ & $\begin{array}{c}\text { Raia River @ } \\
\text { Kampung } \\
\text { Tanjung }\end{array}$ & $\begin{array}{c}\text { Raia River@ } \\
\text { Batu Gajah }\end{array}$ & $\begin{array}{c}\text { Kinta River @ } \\
\text { Ipoh }\end{array}$ & $\begin{array}{c}\text { Pari River @ } \\
\text { Manjoi }\end{array}$ & $\begin{array}{c}\text { Pari River@ } \\
\text { Buntong }\end{array}$ \\
\hline No. of sample & 21 & 20 & 21 & 20 & 20 & 20 \\
\hline Discharge, $Q\left(\mathrm{~m}^{3} / \mathrm{s}\right)$ & $7.98-17.94$ & $3.60-8.46$ & $4.44-17.44$ & $3.80-9.65$ & $9.72-47.90$ & $9.66-17.04$ \\
\hline Water surface width, $B(\mathrm{~m})$ & $20.2-21.1$ & $22.2-25.6$ & $17.3-20.8$ & $24.6-28.0$ & 20.3 & $19.3-19.5$ \\
\hline Flow depth, $y_{o}(\mathrm{~m})$ & $0.55-1.28$ & $0.24-0.49$ & $0.41-1.76$ & $0.35-0.57$ & $0.69-1.87$ & $0.68-0.89$ \\
\hline Hydraulic radius, $R(\mathrm{~m})$ & $0.52-1.14$ & $0.23-0.47$ & $0.39-1.51$ & $0.31-0.55$ & $0.65-1.77$ & $0.63-0.81$ \\
\hline Water surface slope, $S_{o}$ & 0.0010 & 0.0036 & 0.0017 & 0.0011 & 0.0011 & 0.0012 \\
\hline Mean sediment size, $d_{50}(\mathrm{~mm})$ & $0.85-1.10$ & $0.60-1.60$ & $0.50-0.85$ & $0.40-1.00$ & $1.70-3.00$ & $0.85-1.20$ \\
\hline Manning $n$ & $0.031-0.052$ & $0.050-0.062$ & $0.037-0.114$ & $0.029-0.044$ & $0.035-0.042$ & $0.029-0.037$ \\
\hline$B / y_{o}$ & $17-38$ & 46-107 & $12-45$ & $48-86$ & $11-29$ & $22-29$ \\
\hline$y_{o} / d_{50}$ & $539.8-1277.2$ & $182.3-559.3$ & $589.4-2708.0$ & $346.3-1154.9$ & $314.7-738.4$ & $587.8-978.9$ \\
\hline$R / d_{50}$ & $510.4-1140.4$ & $178.3-544.7$ & $564.2-2316.0$ & $337.5-1118.0$ & $294.6-640.5$ & $547.8-901.9$ \\
\hline Bed load, $T_{b}(\mathrm{~kg} / \mathrm{s})$ & $0.40-1.25$ & $0.20-1.82$ & $0.25-1.37$ & $0.02-1.21$ & $0.40-0.80$ & $0.35-0.79$ \\
\hline Suspended load, $T_{s}(\mathrm{~kg} / \mathrm{s})$ & $0.10-1.49$ & $0.07-1.39$ & $0.09-2.04$ & $0.21-12.31$ & $0.79-16.81$ & $0.67-4.41$ \\
\hline Total load, $T_{j}(\mathrm{~kg} / \mathrm{s})$ & $0.57-2.47$ & $0.65-2.11$ & $0.47-2.69$ & $0.23-12.82$ & $1.25-17.62$ & $1.03-4.89$ \\
\hline
\end{tabular}

Table 3 Range of field data for Langat River catchment (Ariffin, 2004).

\begin{tabular}{lcc}
\hline Study site & $\begin{array}{c}\text { Langat River @ } \\
\text { Kajang }\end{array}$ & $\begin{array}{c}\text { Langat River @ } \\
\text { Dengkil }\end{array}$ \\
\hline No. of sample & 20 & 3 \\
Discharge, $Q\left(\mathrm{~m}^{3} / \mathrm{s}\right)$ & $3.75-39.56$ & $33.49-87.79$ \\
Water surface width, $B(\mathrm{~m})$ & $15.0-20.0$ & $30.0-33.0$ \\
Flow depth, $y_{o}(\mathrm{~m})$ & $0.45-1.39$ & $1.90-3.23$ \\
Hydraulic radius, $R(\mathrm{~m})$ & $0.42-1.22$ & $1.70-2.66$ \\
Water surface slope, $S_{o}$ & $0.0043-0.0051$ & 0.0167 \\
Mean sediment size, $d_{50}(\mathrm{~mm})$ & $0.37-2.13$ & $0.52-0.95$ \\
Manning $n$ & $0.049-0.081$ & $0.273-0.345$ \\
$B / y_{o}$ & $14.4-33.5$ & $9.30-17.4$ \\
$y_{o} / d_{50}$ & $292.6-2055.7$ & $3004.4-3626.6$ \\
$R / d_{50}$ & $273.6-1885.6$ & $2585.2-3249.9$ \\
Bed load, $T_{b}(\mathrm{~kg} / \mathrm{s})$ & $0.02-1.29$ & $0.27-0.65$ \\
Suspended load, $T_{s}(\mathrm{~kg} / \mathrm{s})$ & $0.66-77.51$ & $18.69-118.31$ \\
Total load, $T_{j}(\mathrm{~kg} / \mathrm{s})$ & $0.78-77.86$ & $18.96-118.93$ \\
\hline
\end{tabular}

Table 2 to Table 4 show a summary with ranges for discharge $(Q)$, water-surface width $(B)$, flow depth $\left(y_{o}\right)$, hydraulic radius $(R)$, water-surface slope $\left(S_{o}\right)$, mean sediment size $\left(d_{50}\right)$, aspect ratio $\left(B / y_{o}\right)$, flow resistance parameters $\left(y_{o} / d_{50}\right.$ and $\left.R / d_{50}\right)$, bed load $\left(T_{b}\right)$, suspended load $\left(T_{s}\right)$ and total bed material load $\left(T_{j}\right)$. The mean sediment sizes for all sites show that the study reaches are sand-bed streams where $d_{50}$ ranges from 0.40 to $2.0 \mathrm{~mm}$. The aspect ratios for the three rivers are between 11 and 107 indicating that they are moderate-size channels. The water-surface slopes of the study reaches were determined by taking measurements of water levels over a distance of $200 \mathrm{~m}$ where the cross section is located (FISRWG, 2001). For all study sites the water-surface slopes were found to be mild with ranges between 0.001 and 0.005 . No over bank flow occurred during all measurements.

Low sediment transport rates, $T_{j}$ occurred during the measurements with ranges between 0.01 to $17.62 \mathrm{~kg} / \mathrm{s}$ while the discharges varied between 0.73 and $47.90 \mathrm{~m}^{3} / \mathrm{s}$ for Kinta River
Table 4 Range of field data for Kulim River catchment (Chang, 2006).

\begin{tabular}{lcc}
\hline Study site & $\begin{array}{c}\text { Kulim River @ } \\
\text { CH } 14390\end{array}$ & $\begin{array}{c}\text { Kulim River @ } \\
\text { CH } 3014\end{array}$ \\
\hline No. of sample & 6 & 12 \\
Discharge, $Q\left(\mathrm{~m}^{3} / \mathrm{s}\right)$ & $0.73-3.13$ & $3.73-9.98$ \\
Water surface width, $B(\mathrm{~m})$ & $9.0-13.0$ & $13.0-19.0$ \\
Flow depth, $y_{o}(\mathrm{~m})$ & $0.20-0.54$ & $0.36-0.58$ \\
Hydraulic radius, $R(\mathrm{~m})$ & $0.22-0.57$ & $0.40-0.63$ \\
Water surface slope, $S_{o}$ & 0.001 & 0.001 \\
Mean sediment size, $d_{50}(\mathrm{~mm})$ & $1.00-1.95$ & $1.10-2.00$ \\
Manning $n$ & $0.033-0.053$ & $0.024-0.037$ \\
$B / y_{o}$ & $23.4-44.8$ & $26.0-52.5$ \\
$y_{o} / d_{50}$ & $126.9-369.01$ & $240.0-550.9$ \\
$R / d_{50}$ & $141.4-406.6$ & $266.5-570.9$ \\
Bed load, $T_{b}(\mathrm{~kg} / \mathrm{s})$ & $0.06-0.33$ & $0.11-0.36$ \\
Suspended load, $T_{s}(\mathrm{~kg} / \mathrm{s})$ & $0.02-0.23$ & $0.03-1.21$ \\
Total load, $T_{j}(\mathrm{~kg} / \mathrm{s})$ & $0.09-0.56$ & $0.27-1.35$ \\
\hline
\end{tabular}

and Kulim River. Higher flow discharge occurred at Langat River up to $88 \mathrm{~m}^{3} / \mathrm{s}$ that resulted in higher sediment transport rates up to $119 \mathrm{~kg} / \mathrm{s}$.

\section{Data analysis}

Figures 10 to 12 illustrate the variation of Manning $n$ with flow depths and discharges for the three rivers in the present study. Five cross sections along Kinta River (Figure 10) show that $n$ increases with the increase in both flow depth and discharge. This could be attributed to grassy banks (Figure 5) and irregular cross sections. Table 2 shows that the range of $n$ for Kinta River is between 0.03 and 0.060. For Langat River (Figure 11), both study sites show that $n$ decreases with the increase in both flow depths and discharges as occurs in most streams (Chow, 1959). The range of $n$ for Langat River as given in Table 3 is between 0.05 and 0.35. As for the Kulim River (Figure 12), CH 14390 

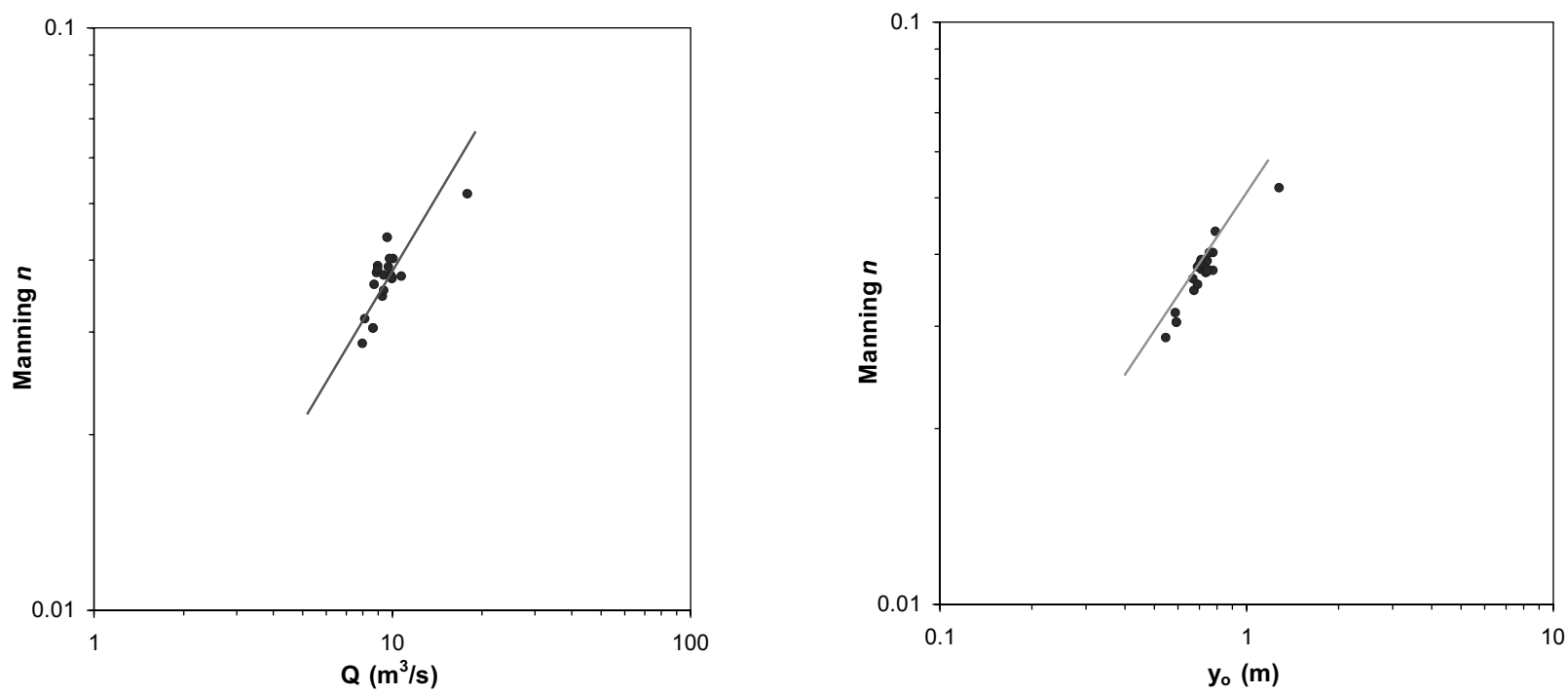

(a) Kampar River @ KM 34
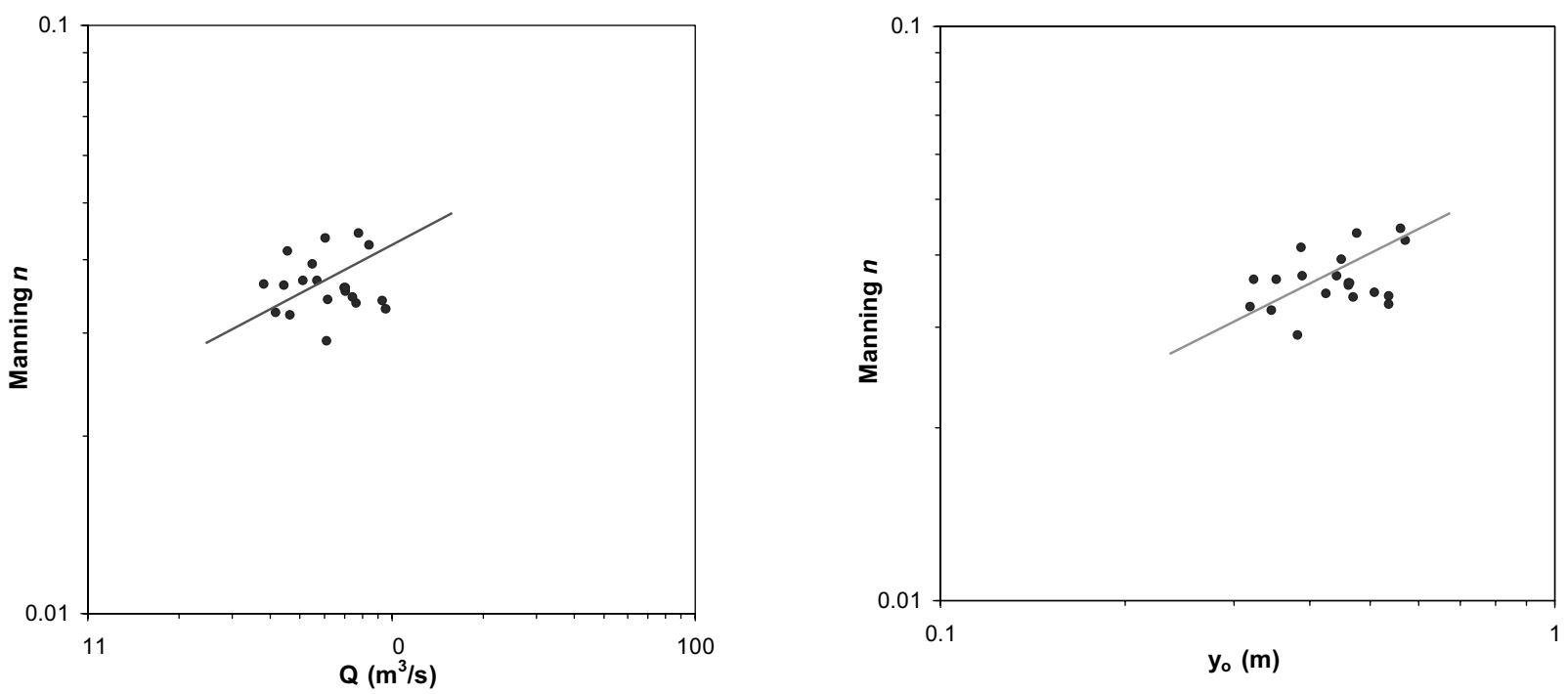

(b) Kinta River
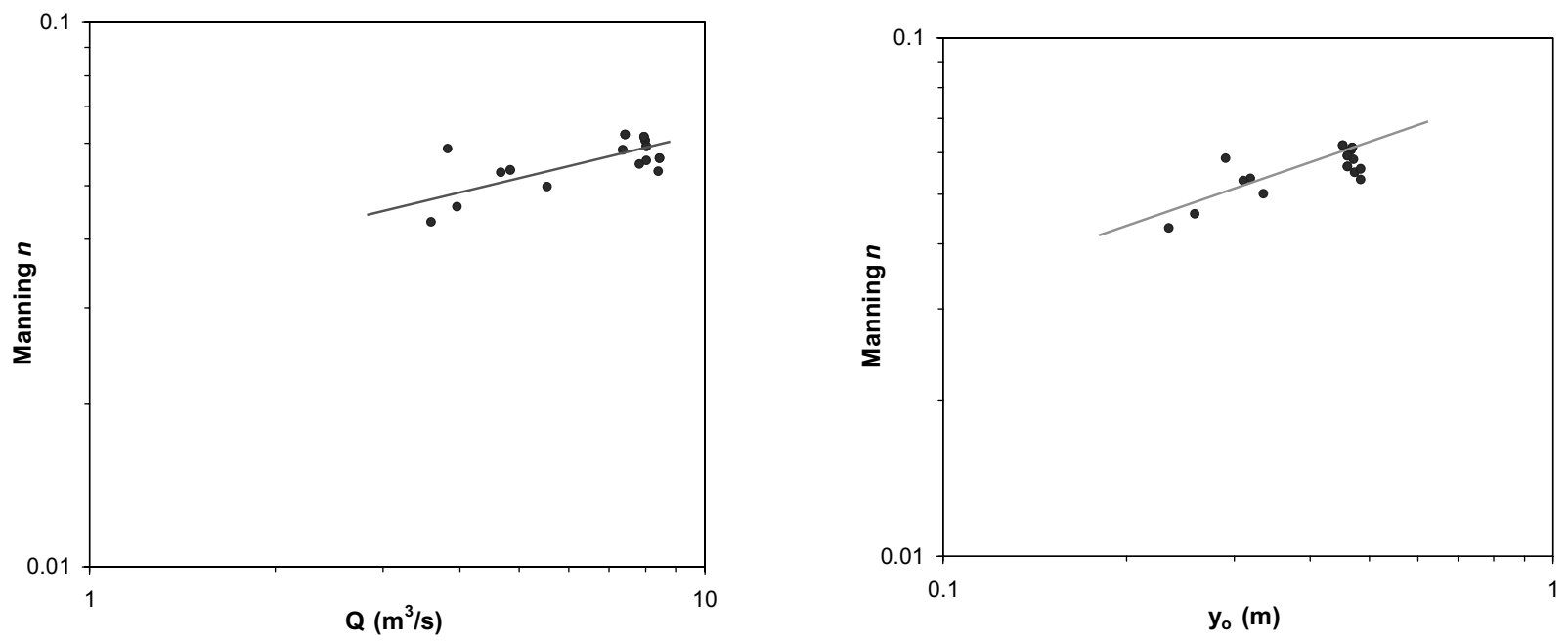

(c)Raia River @ KampungTanjung

Figure 10 Manning $n$ against $Q$ and $y_{o}$ for Kinta River catchment. 

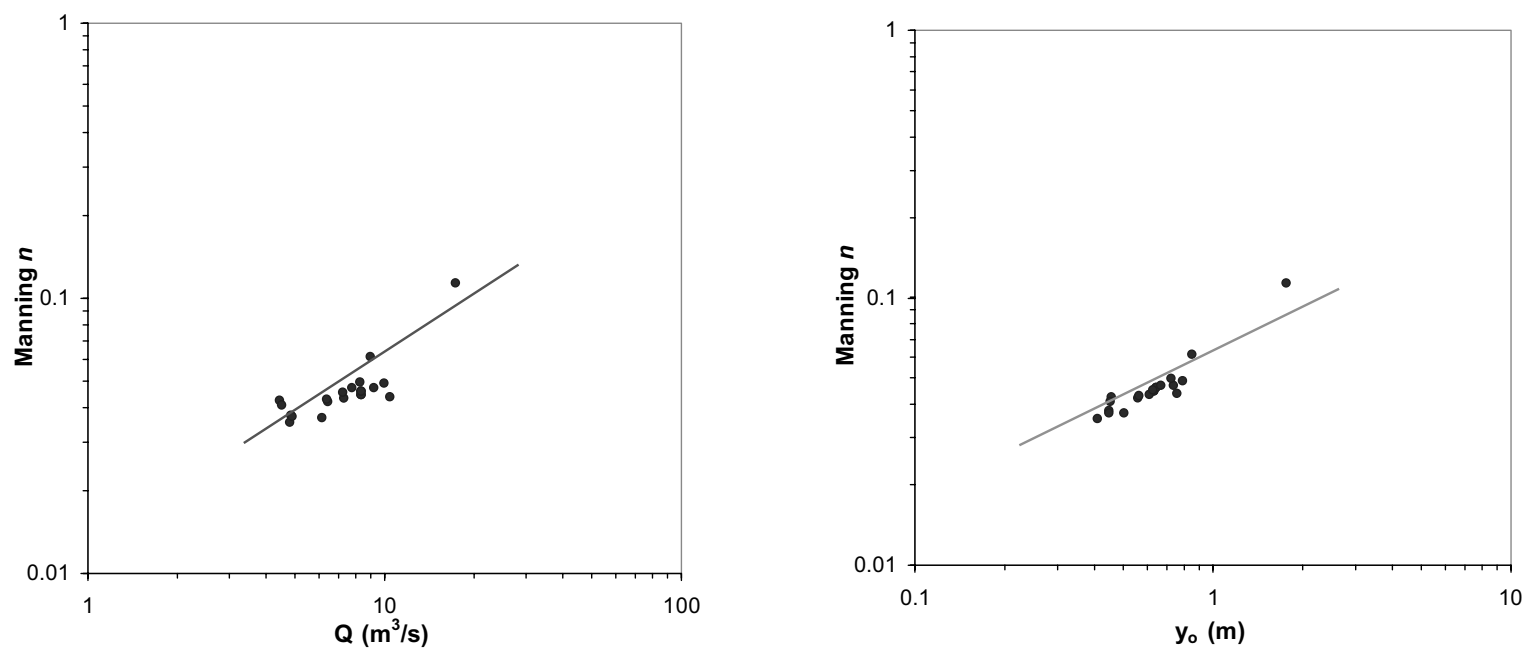

(d) Raia River @ Batu Gajah
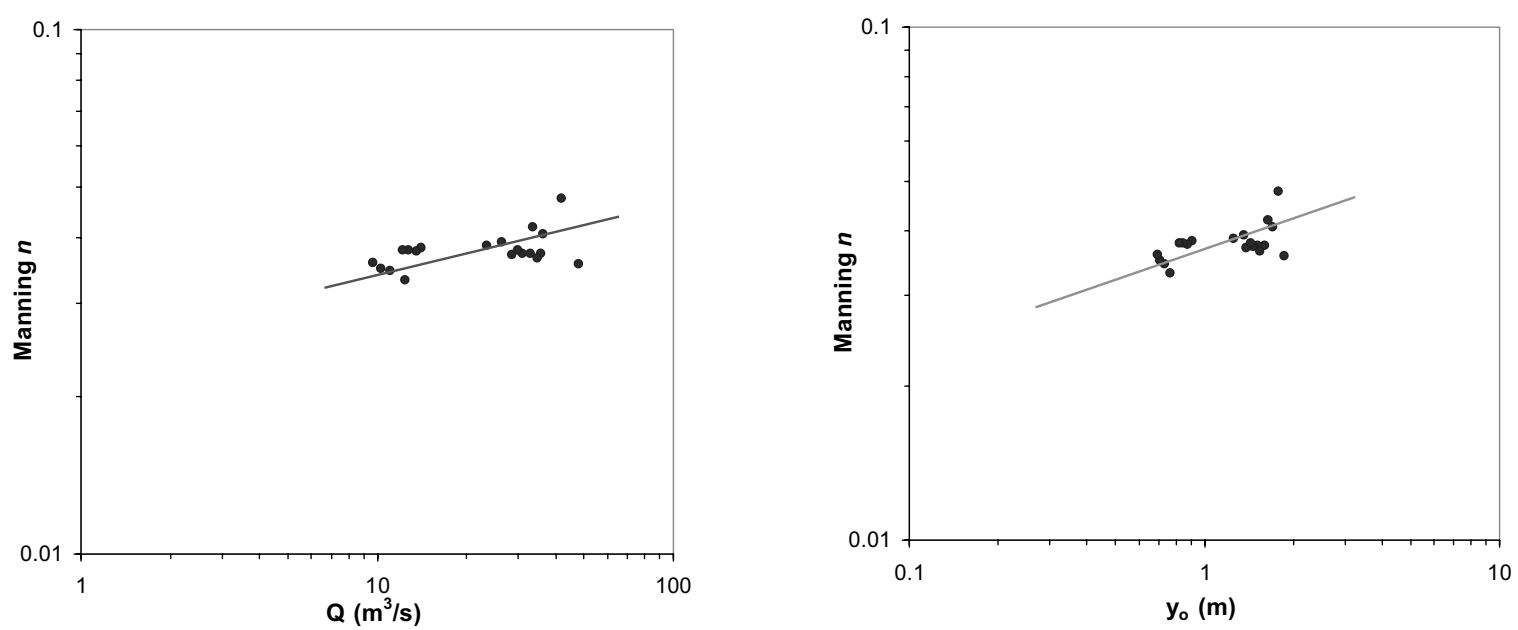

(e) Pari River @ Manjoi
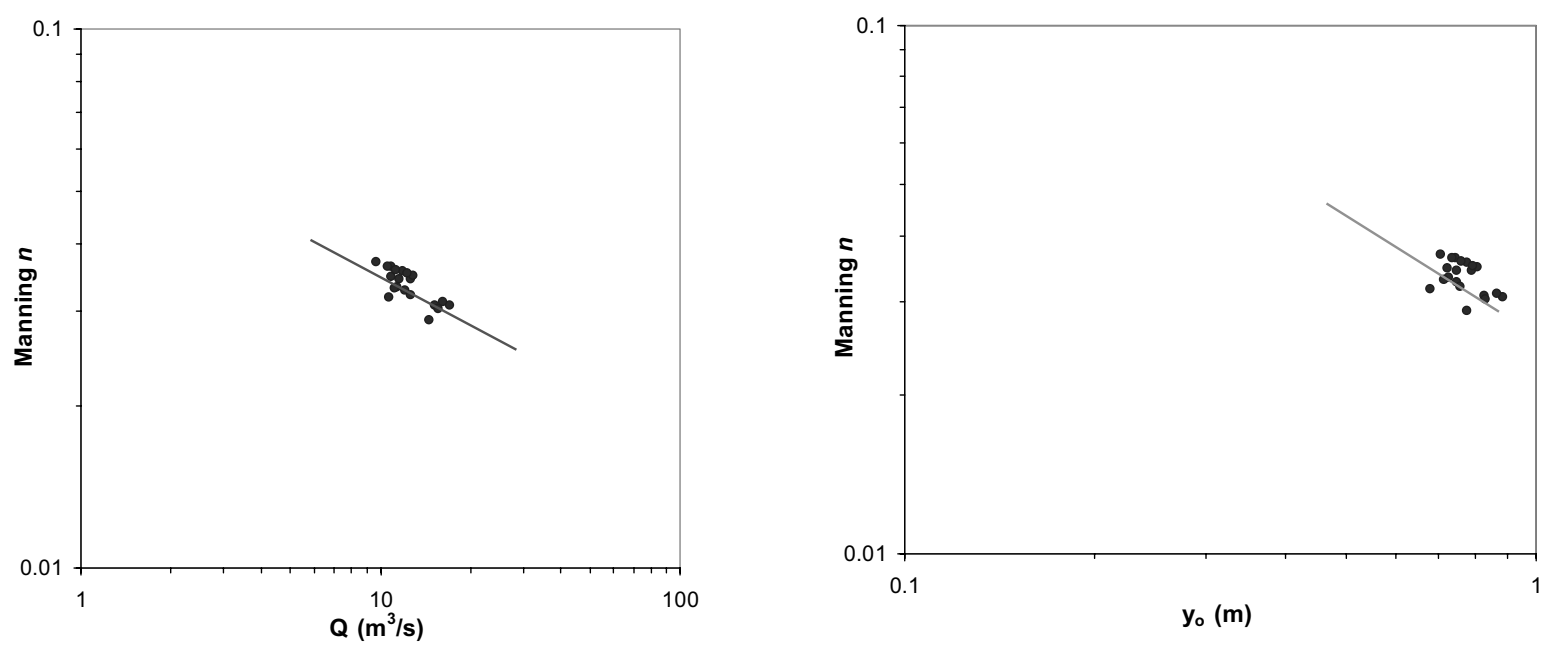

(f) Pari River @ Buntong

Figure 10 (Continued). 

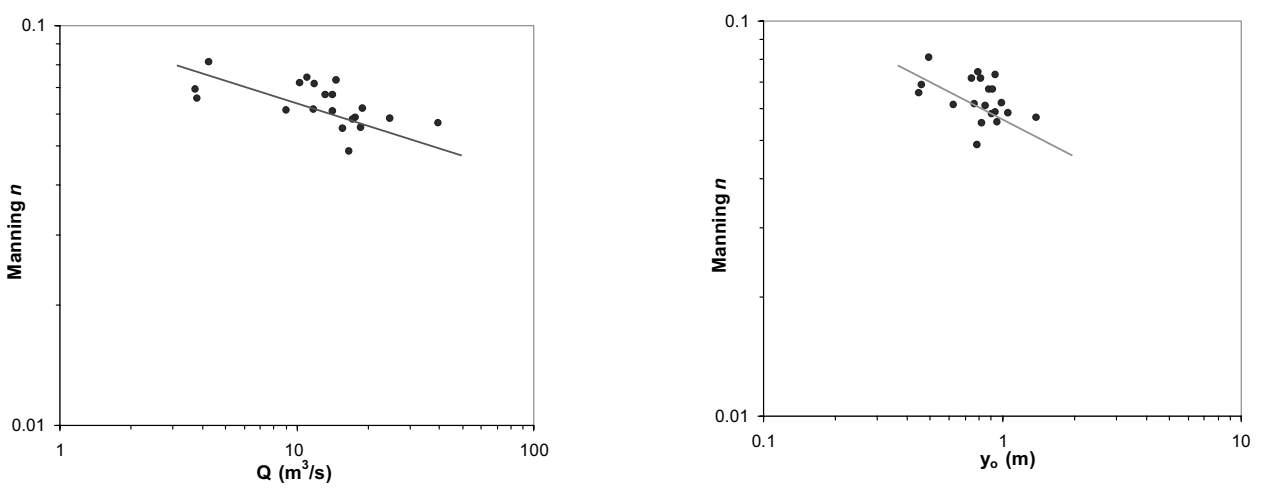

(a) Langat River @ Kajang
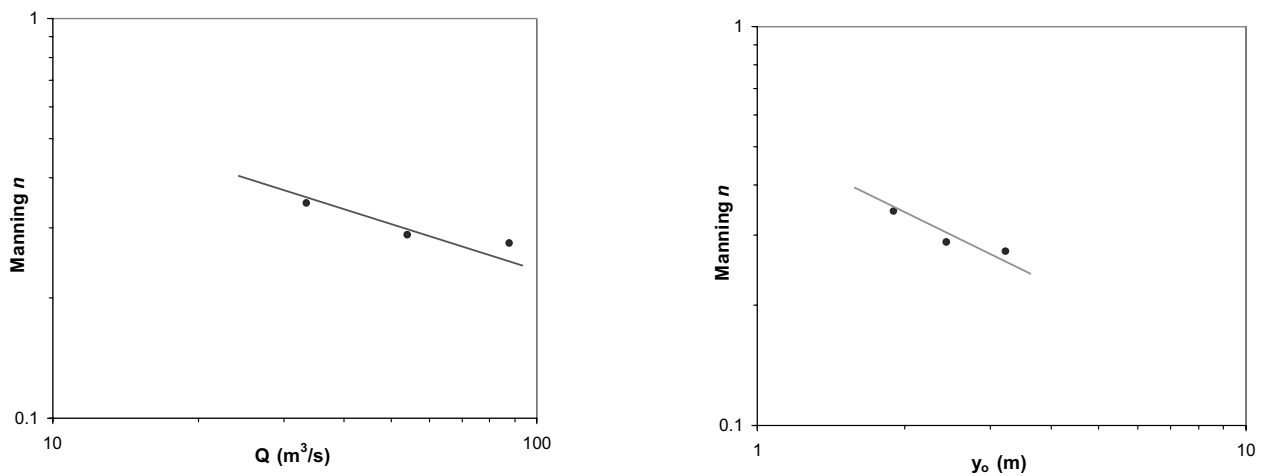

(b) Langat River @ Dengkil

Figure 11 Manning $n$ against $Q$ and $y_{o}$ for Langat River catchment.
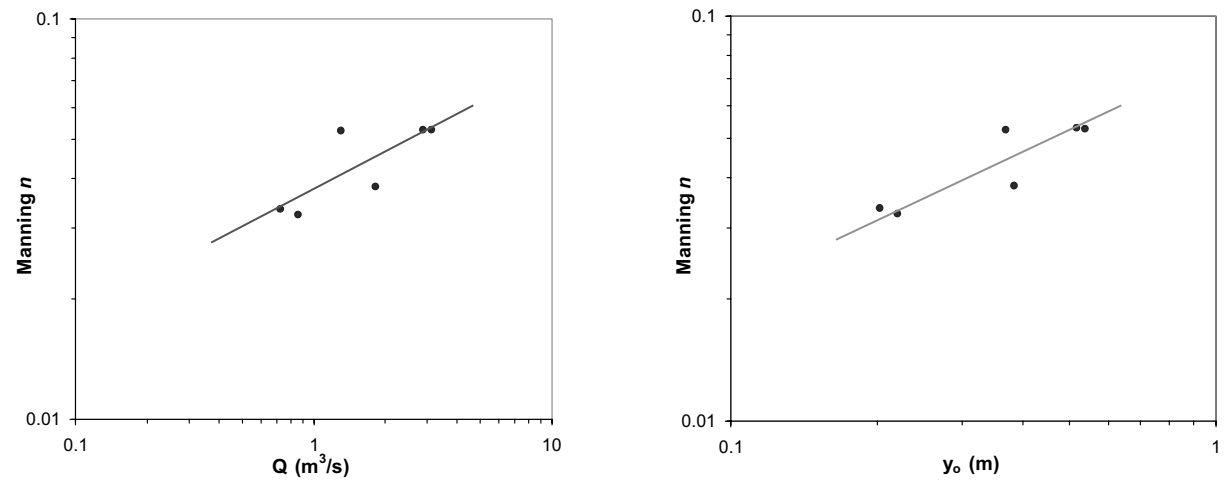

(a) Kulim River @ CH 14390
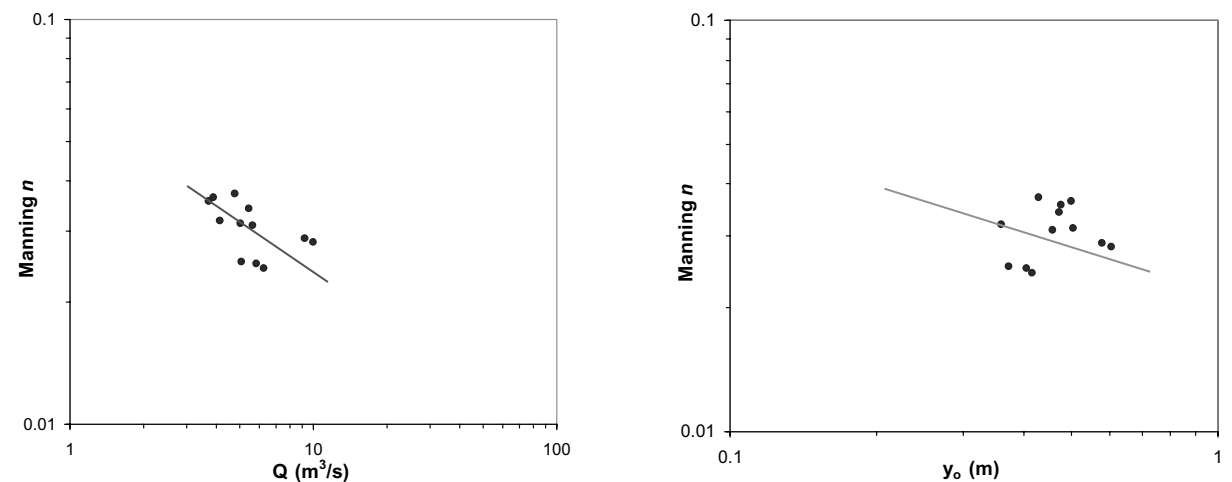

(b) Kulim River @ CH 3014

Figure 12 Manning $n$ against $Q$ and $y_{o}$ for Kulim River catchment. 


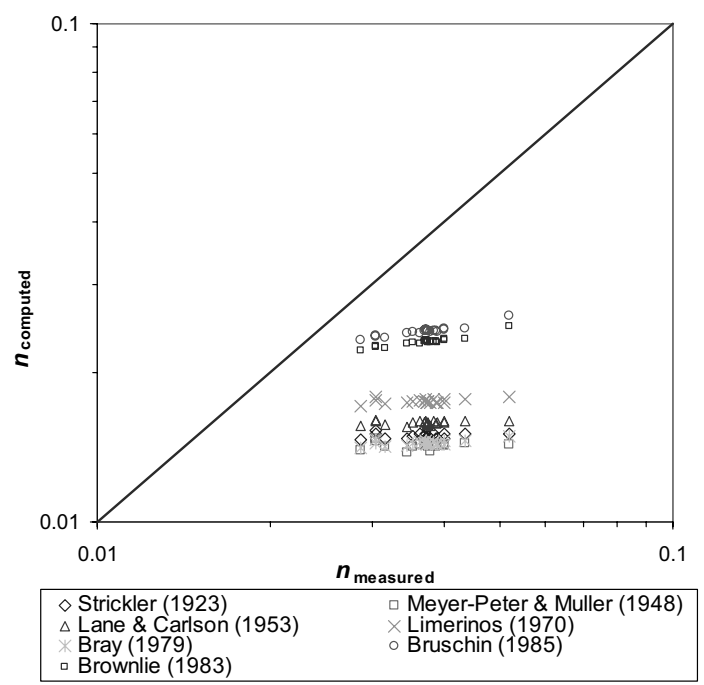

(a) Kampar River @KM 34

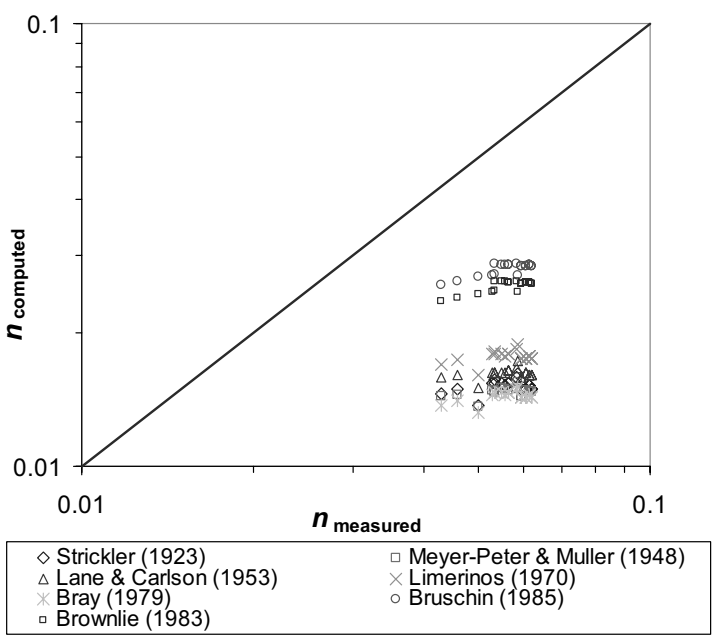

(c) Raia River @Kampung Tanjung

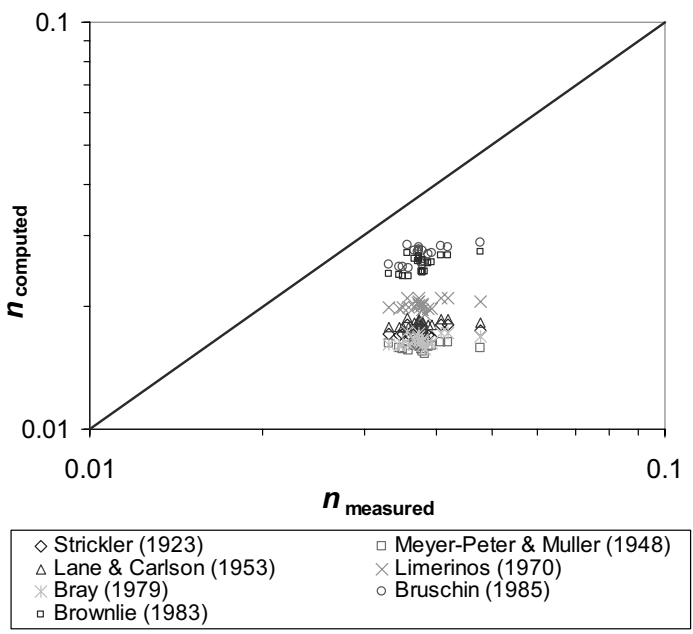

(e) Pari River @ Manjoi

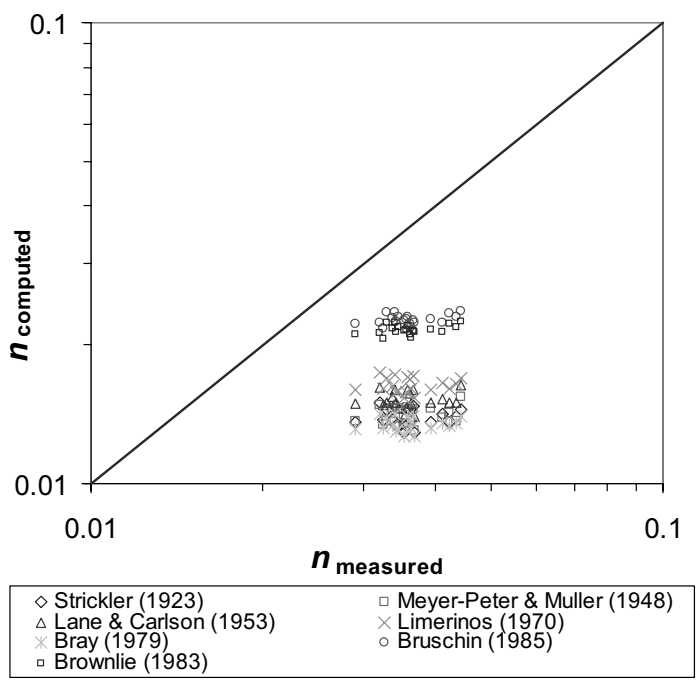

(b) Kinta River

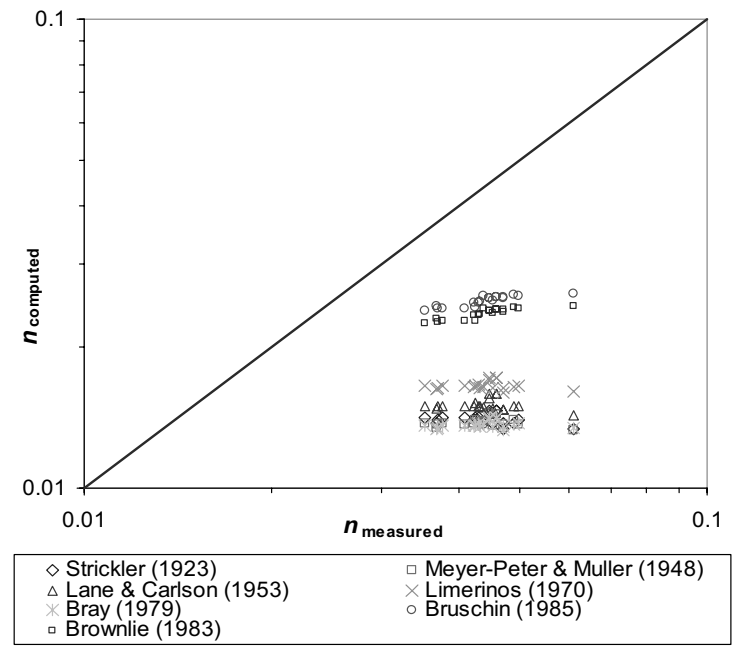

(d) RaiaRiver @ Batu Gajah

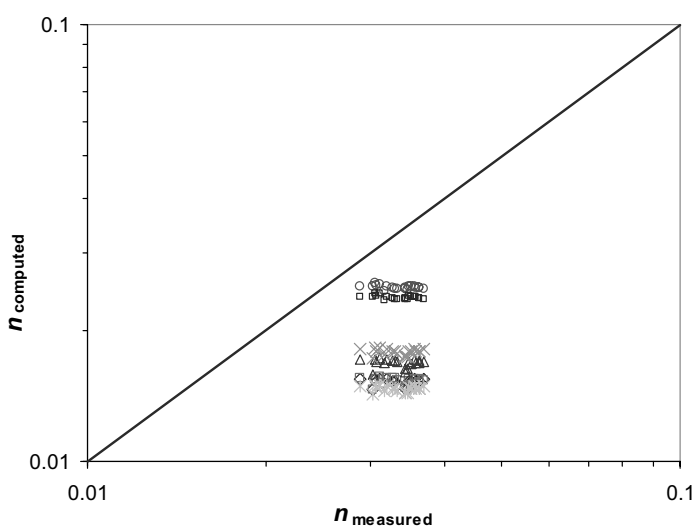

$\begin{array}{ll}\diamond \text { Strickler (1923) } & \square \text { Meyer-Peter \& Muller (1948) } \\ \Delta \text { Lane \& Carlson (1953) } & \times \text { Limerinos (1970) } \\ * \text { Bray (1979) } & \circ \text { Bruschin (1985) } \\ \square \text { Brownlie (1983) } & \end{array}$

(f) Pari River @ Buntong

Figure 13 Measured $n$ against computed $n$ based on existing equations for Kinta River catchment. 


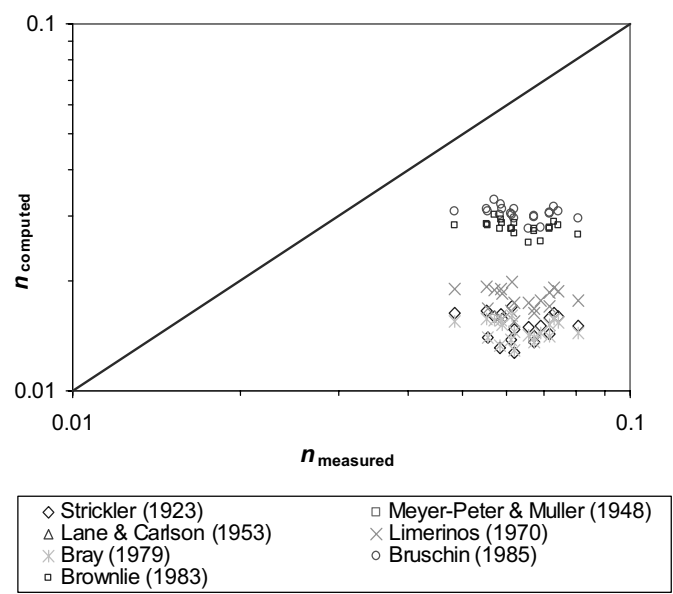

(a) Langat River @ Kajang

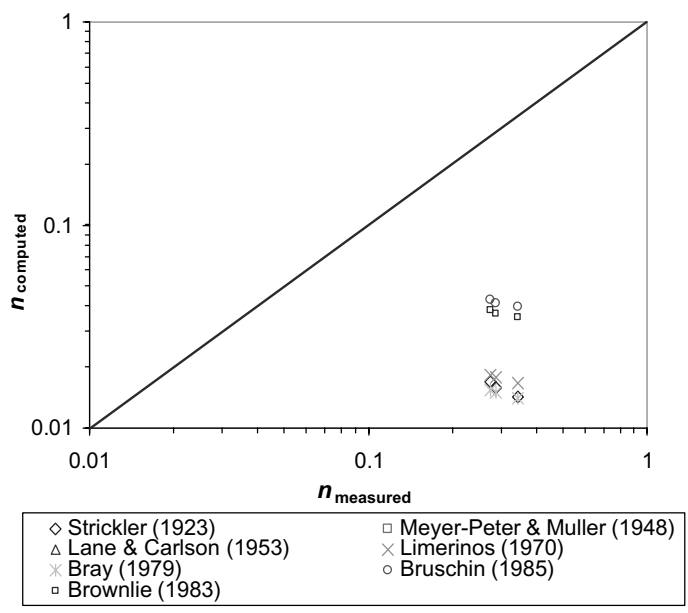

(b) Langat River @ Dengkil

Figure 14 Measured $n$ against computed $n$ based on existing equations for Langat River catchment.

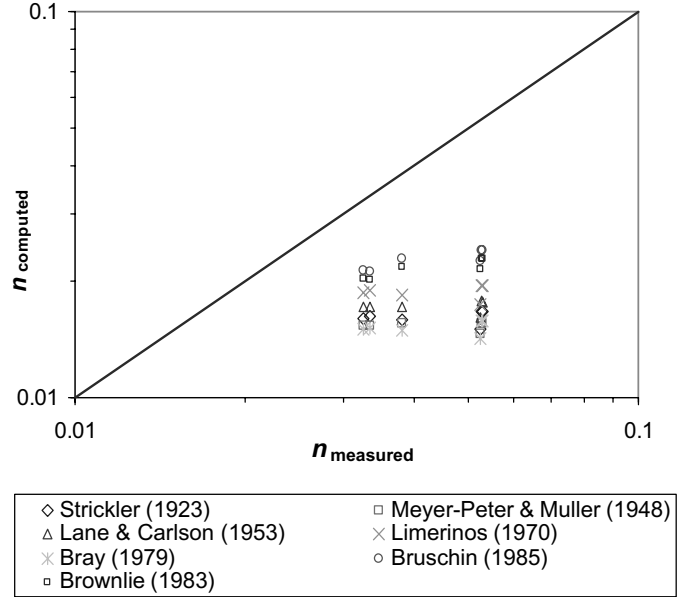

(a) Kulim River @ CH 14390

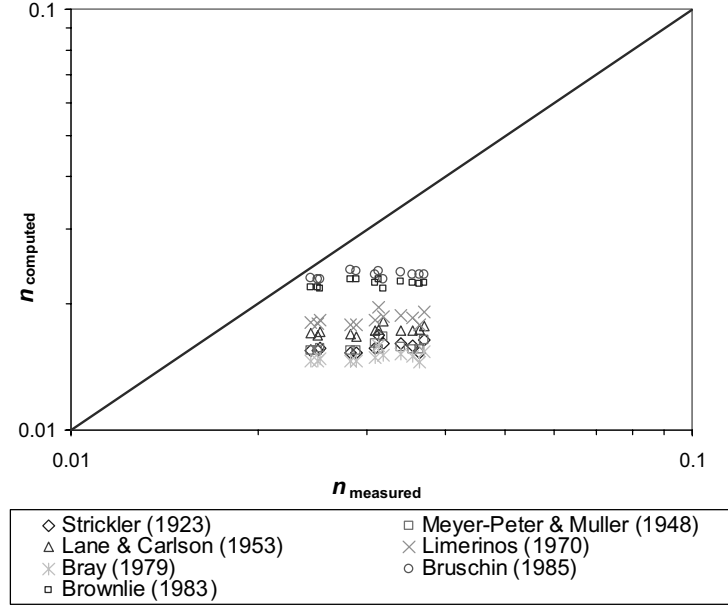

(b) Kulim River @3014

Figure 15 Measured $n$ against computed $n$ based on existing equations for Kulim River catchment.

at the upstream shows that $n$ increases with both flow depth and discharge while at $\mathrm{CH} 3014$ at the downstream, $n$ decreases with both flow depths and discharges. The range of $n$ for Kulim River (Table 4) is between 0.024 and 0.053 .

These values of $n$ obtained at the three rivers suggest that the streams are natural channels with somewhat irregular side slopes and grass on slopes as given in Table 1 (Chow, 1959).

\section{Evaluation of existing equations}

The evaluations of Equations 1 to 7 for the three rivers are shown in Figures 13 to 15. Examples of measured and computed $n$ from the seven equations for representative data are given in Tables 5 to 7. The ranges of $n$ predicted by these seven equations are between 0.010 and 0.040 . Figures 13 to 15 show that all existing equations underestimate the measured $n$ values for all three rivers. As a consequence, these results in an unsatisfactory overprediction of discharge as depicted in Figures 16 to 18.
Equations 1 to 3 were developed for large rivers hence the results show that they are not directly applicable for the moderatesize channels in the present study. Similarly, Equations 4 and 5 were based on data from gravel-bed streams; the results obtained also show that these two equations do not apply well for sandbed streams for the three rivers in the present study. Even though Equations 6 and 7 were based on sandy river data, they are also not applicable perhaps due to the presence of grassy banks and channel irregularities in the present cross sections as discussed earlier.

The pattern in error as shown in Figures 13 to 15 suggests an improved equation needs to be developed for these three rivers in the present study in particular and other rivers having similar characteristics in general.

\section{Development of new equations}

Since the sand-bed streams in the present study are moderate-size channels with an aspect ratio between 11 and 107 and of mild slope (0.001-0.005), attempts were made to derive new equations 


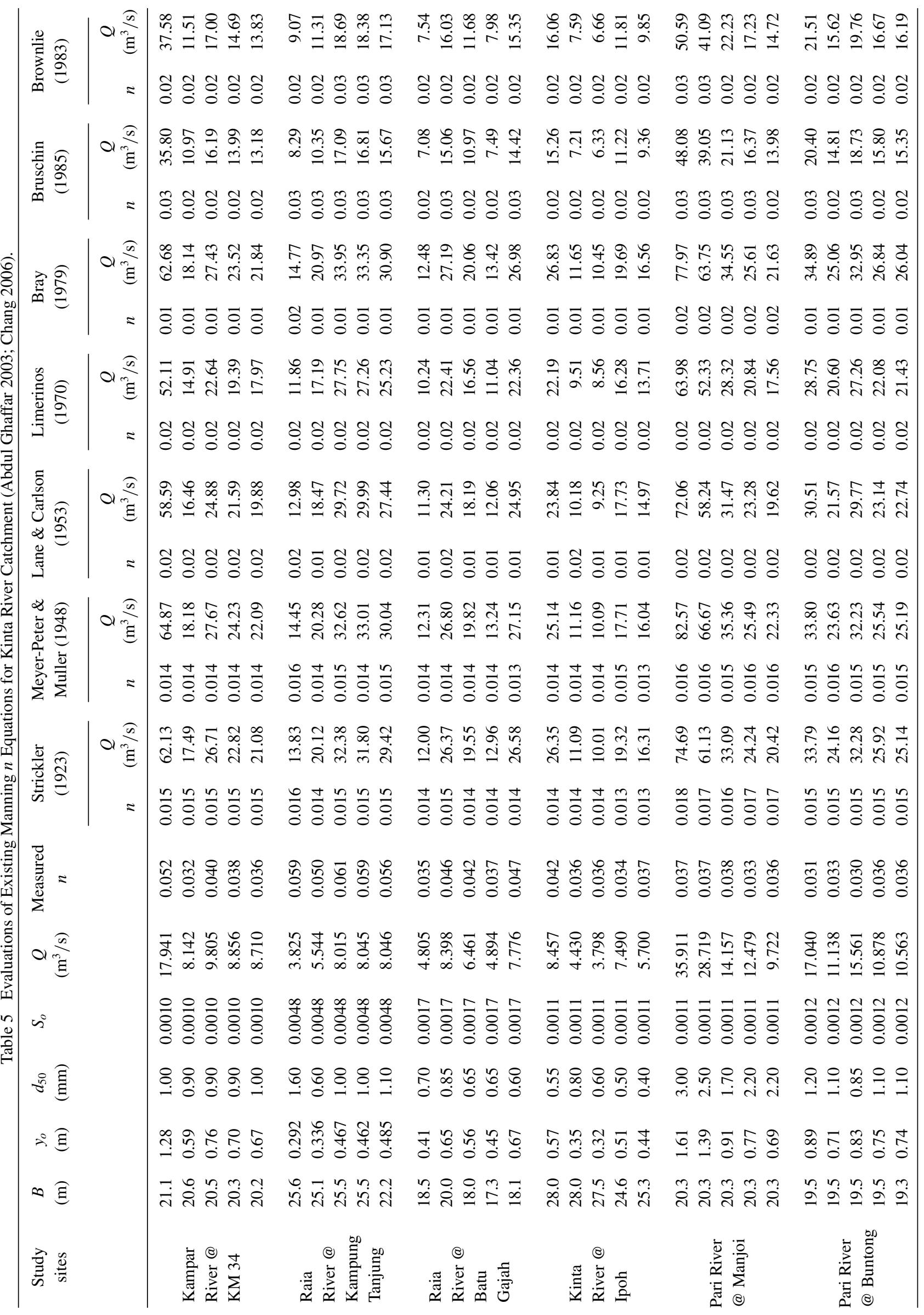




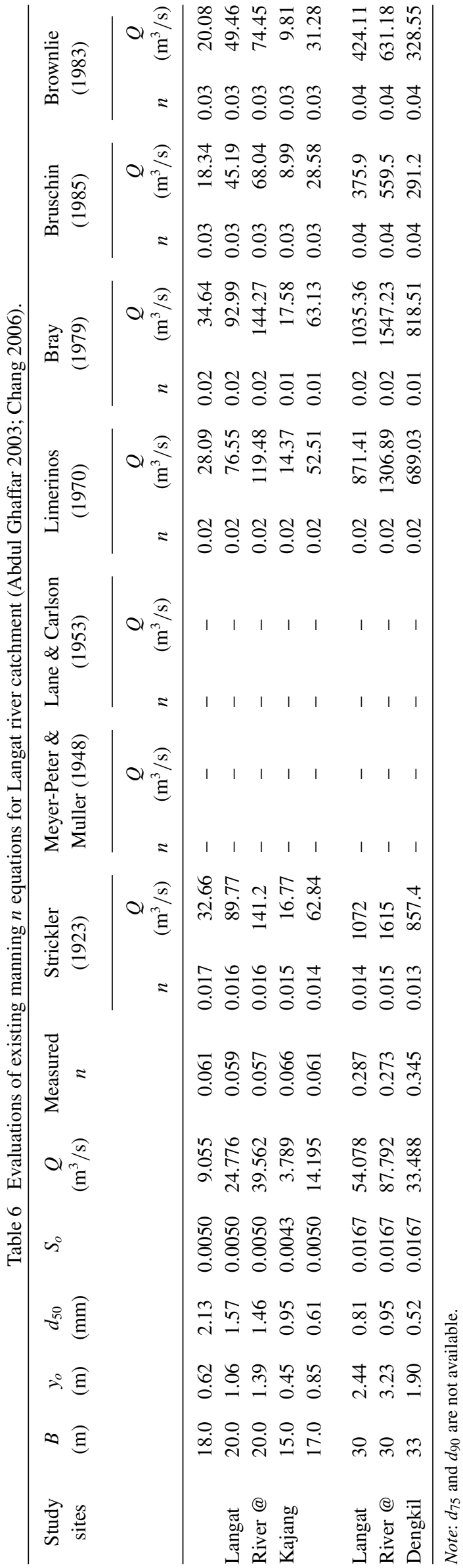

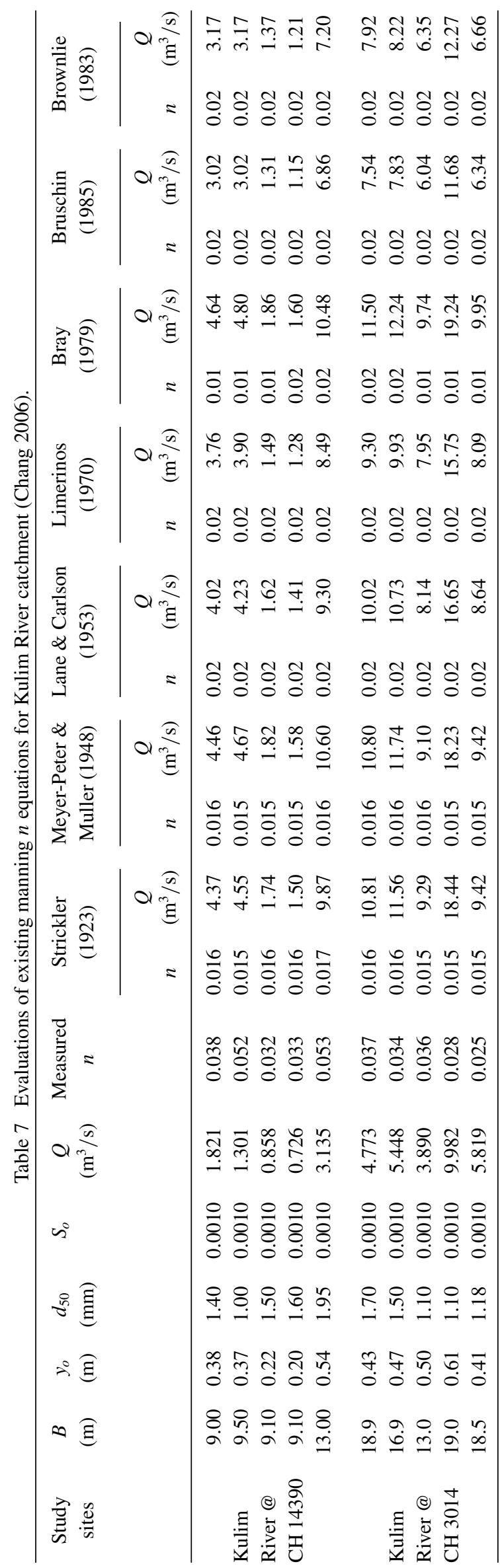




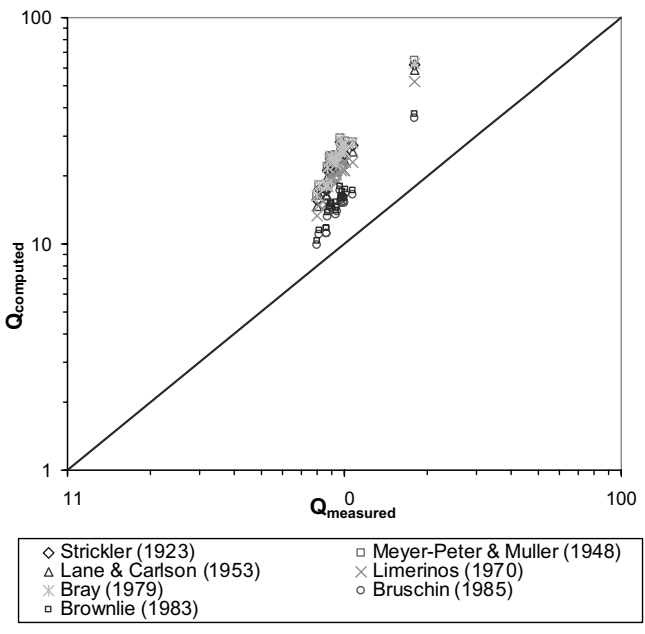

(a) Kampar River @KM 34

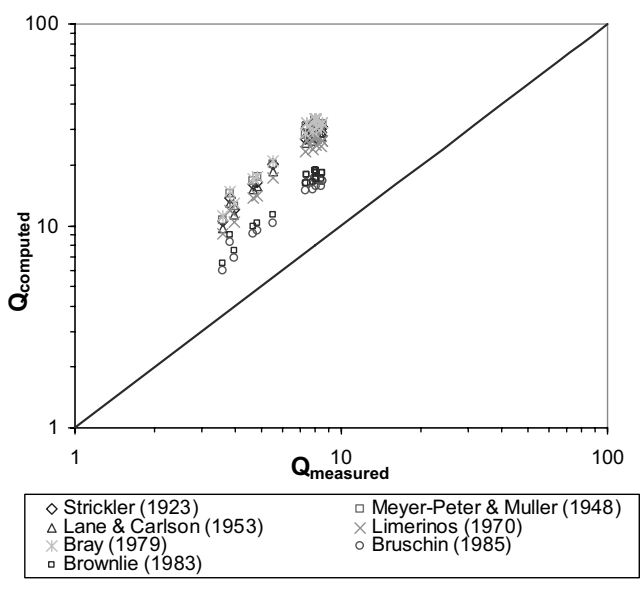

(c) Raia River@ Kampung Tanjung

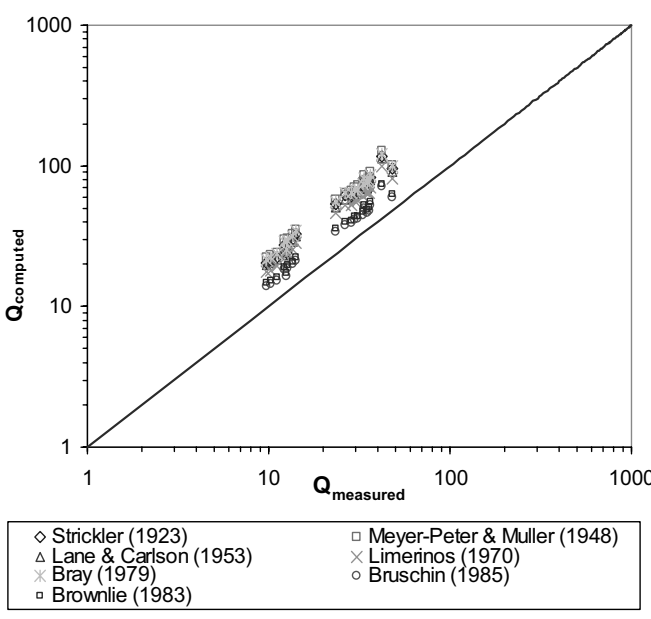

(e) Pari River @ Manjoi

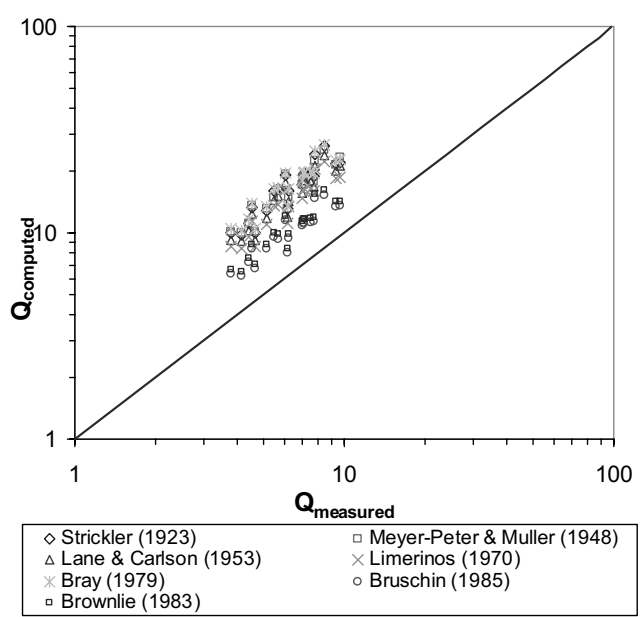

(b) Kinta River

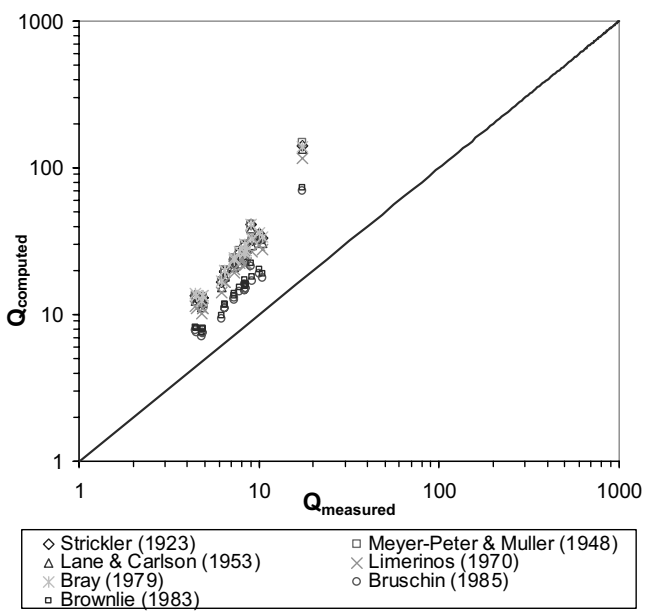

(d) Raia River@ Batu Gajah

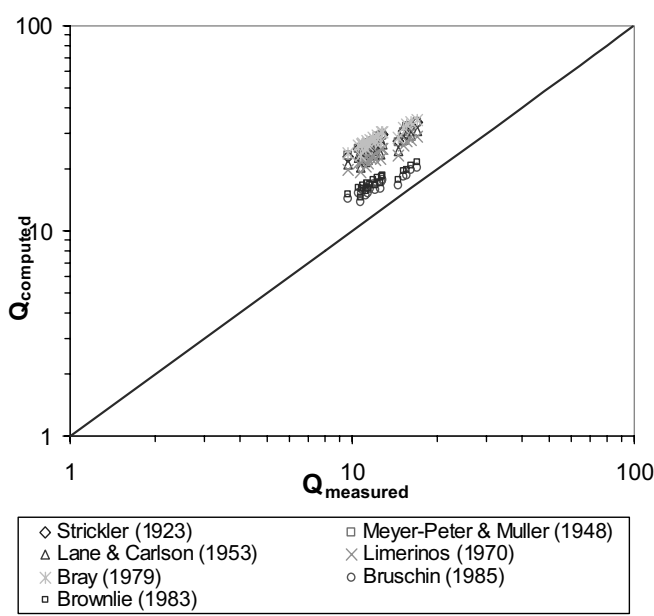

(f) Pari River @ Buntong

Figure 16 Measured $Q$ against computed $Q$ based on existing equations for Kinta River catchment. 


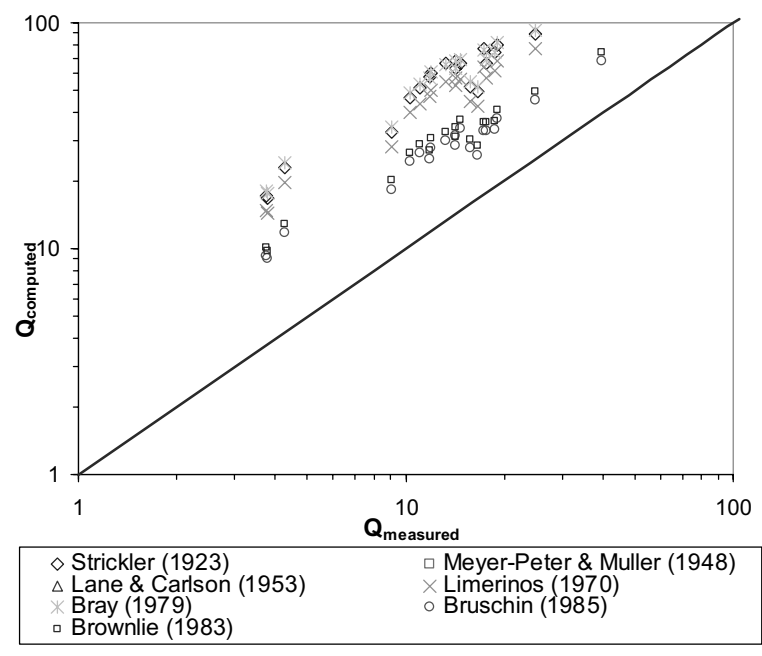

(a) Langat River @ Kajang

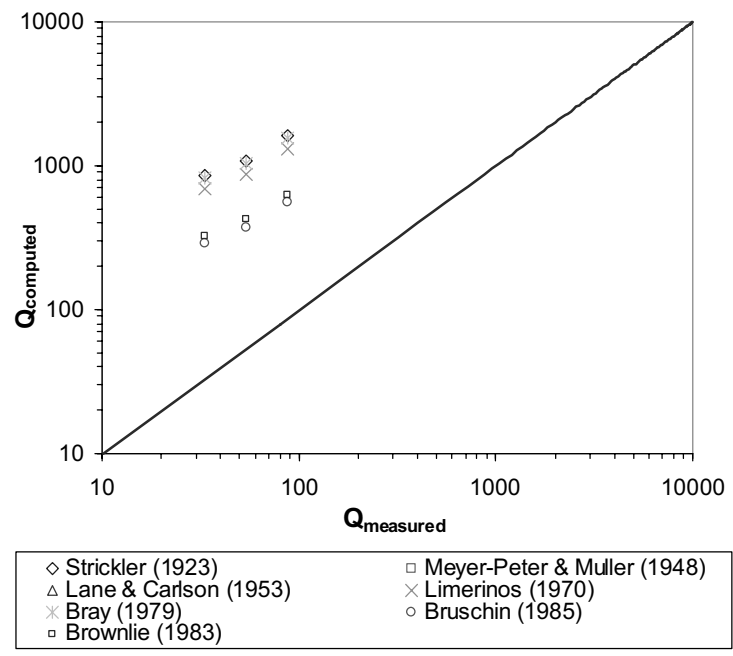

(b) Langat River @ Dengkil

Figure 17 Measured $Q$ against computed $Q$ based on existing equations for Langat River catchment.

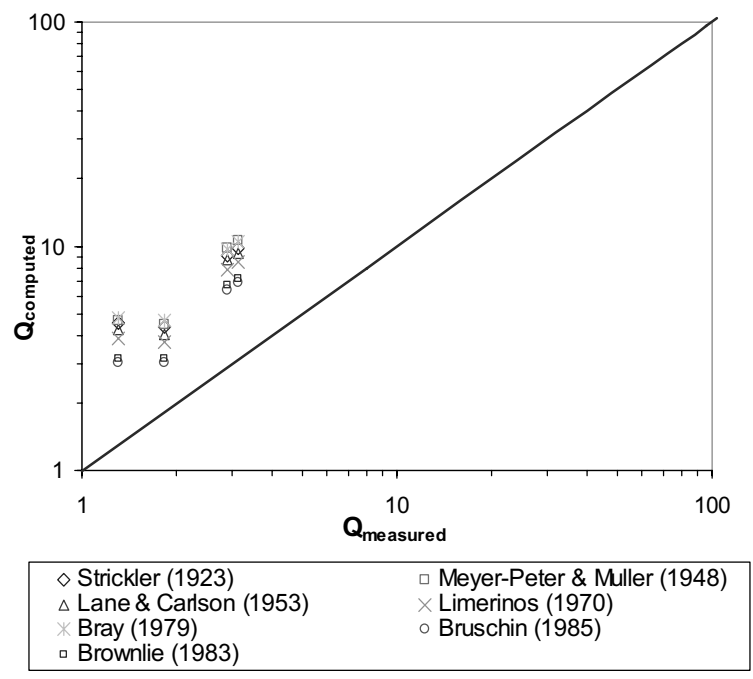

(a) Kulim River @ CH 14390

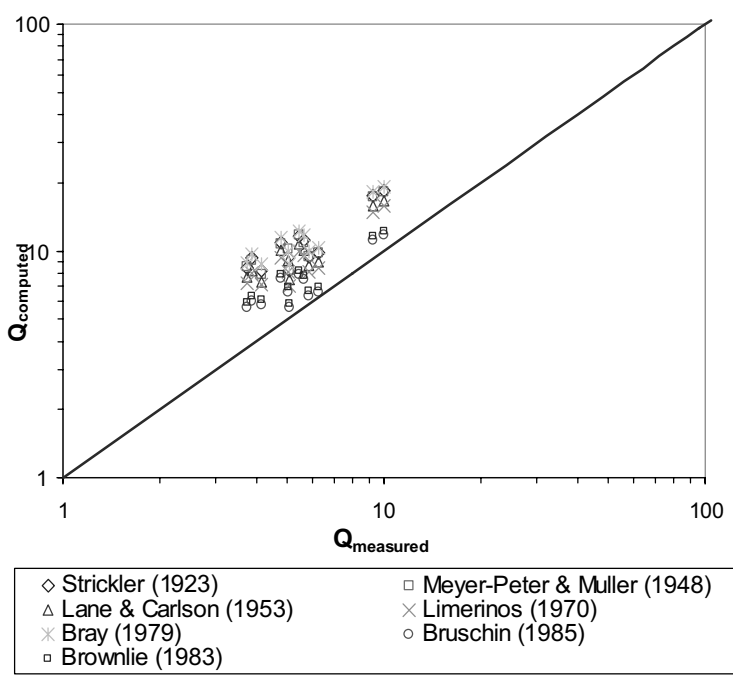

(b) Kulim River @3014

Figure 18 Measured $Q$ against computed $Q$ based on existing equations for Kulim River catchment.

for Manning $n$. Based on the parameters used in Equations 1 to 7 , the best parameters to use are $y_{0} / d_{50}$, and $R / d_{50}$ (Abdul Ghaffar, 2003). Figures 19 and 20 plot Manning's $n$ against both $y_{o} / d_{50}$, and $R / d_{50}$, respectively.

The following two equations (Chang, 2006) are recommended for determining Manning $n$ for moderate-size and sand-bed streams in Malaysia with a regression coefficient $R^{2}=0.86$ :

$$
\begin{aligned}
& n=4 \times 10^{-8}\left(\frac{y_{o}}{d_{50}}\right)^{2}-5 \times 10^{-5}\left(\frac{y_{o}}{d_{50}}\right)+0.0582 \\
& n=5 \times 10^{-8}\left(\frac{R}{d_{50}}\right)^{2}-7 \times 10^{-5}\left(\frac{R}{d_{50}}\right)+0.0622
\end{aligned}
$$

Both equations confirm that Manning $n$ are affected by the variation in flow depth and mean sediment size as found by Strickler (1923), Meyer-Peter \& Muller (1948), Limerinos (1970), Bray (1979), Bruschin (1985), and Julien (2002).

Table 8 gives a summary of accuracy for Equations 8 and 9 based on the discrepancy (ratio of computed discharge over measured discharge) for all the 168 data. The results show that $65 \%$ of all the data are within \pm 0.25 range of discrepancy ratio for Equation 8 (Figure 21) while $72 \%$ of all the data are within \pm 0.25 range of discrepancy ratio for Equation 9 (Figure 22). The average discrepancy ratio of Equation 8 for all 168 river data is 0.93 while for Equation 9 is 1.03 . This means that, on average, both equations have an error between $3 \%$ and $7 \%$ suggesting the viability of using these new equations for predicting flow discharge for the rivers with similar characteristics as studied. 


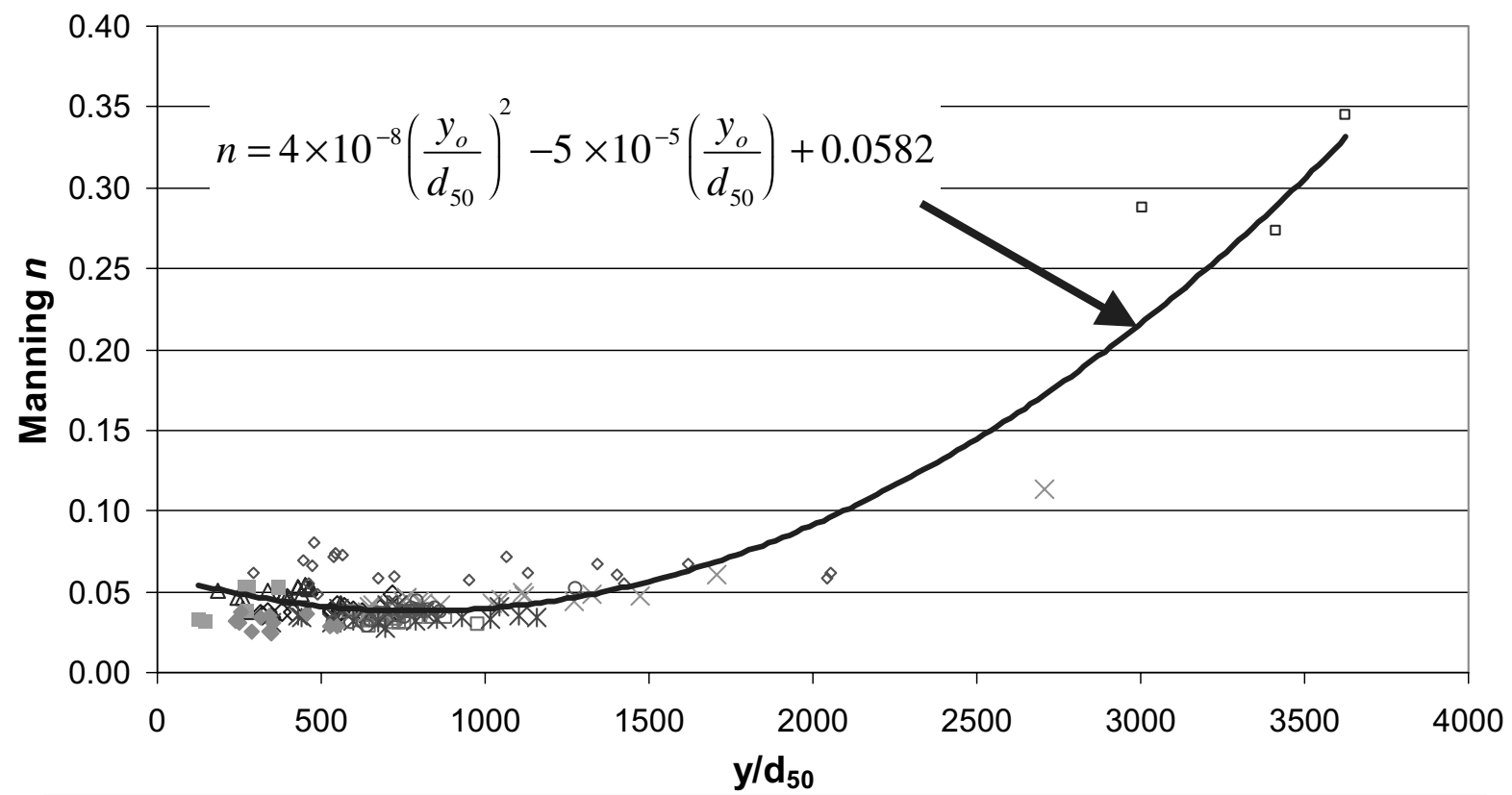

$\diamond$ Pari River@ Manjoi $\quad$ Pari River@ Buntong

$\times$ Raia River@ Batu Gajah

- Langat River@ Kajang

Kulim River@ CH 3014

* Kinta River@Ipoh

- Langat River@ Dengkil $\triangle$ Raia River@ @g Tanjung

- Kampar River@ KM 34

- Kulim River@ CH14390

Figure 19 Manning $n$ against $y_{o} / d_{50}$.

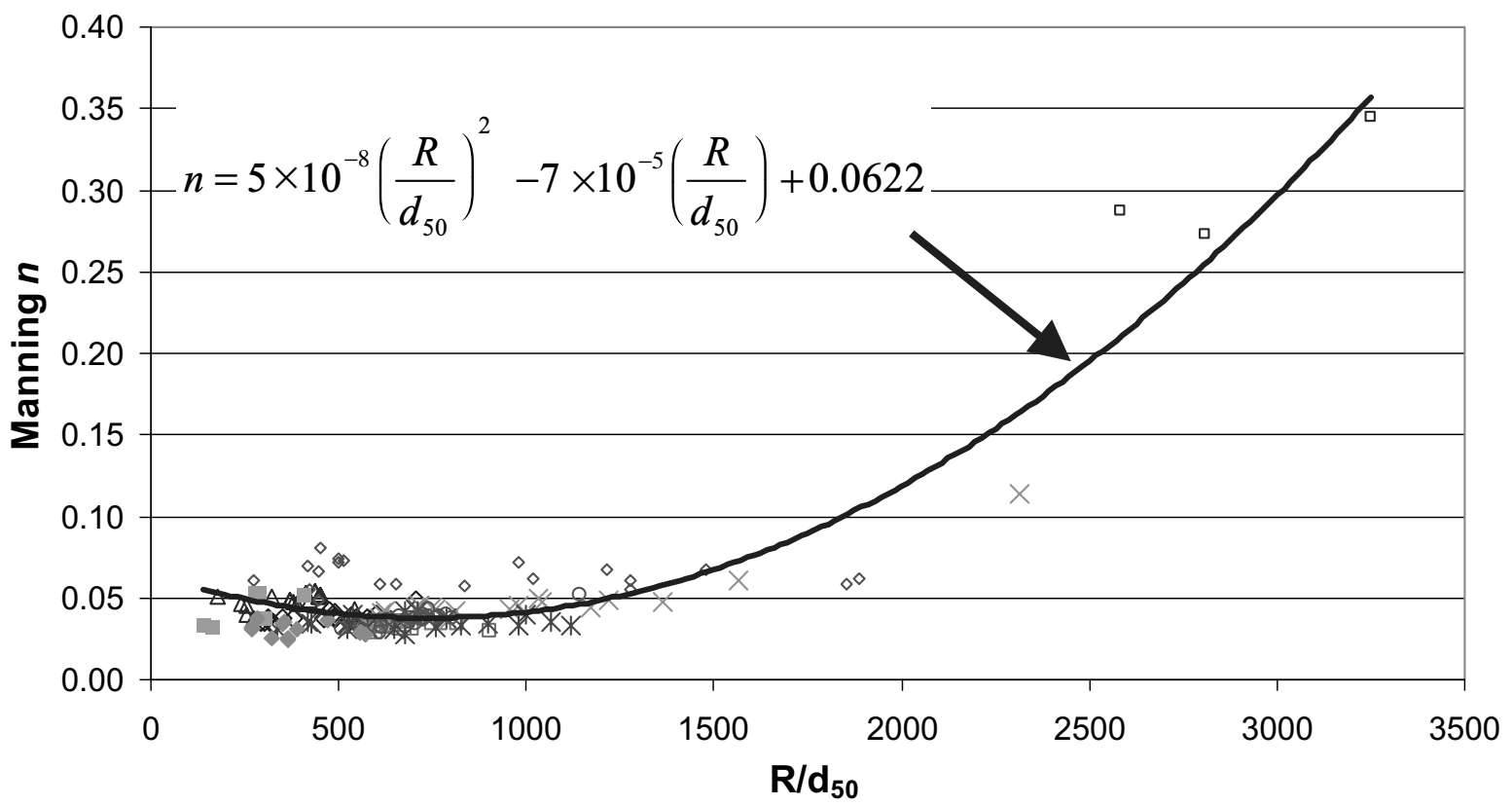

$\diamond$ Pari River@ Manjoi

$\times$ Raia River@ Batu Gajah

$\diamond$ Langat River@ Kajang - Kulim River @ CH 3014
- Pari River@Buntong

* Kinta River@ Ipoh

- Langat River@Dengkil $\triangle$ Raia River @ Kg Tanjung

- Kampar River@ KM 34

- Kulim River@ @H14390

Figure 20 Manning $n$ against $R / d_{50}$. 
Table 8 Summary of accuracy of equations 8 and 9 .

\begin{tabular}{|c|c|c|c|c|}
\hline \multirow[t]{2}{*}{ Equation } & \multirow[t]{2}{*}{ River } & \multirow[t]{2}{*}{ Location } & \multicolumn{2}{|c|}{ Discrepancy Ratio } \\
\hline & & & $0.75-1.25(\%)$ & $\overline{\text { Average }}$ \\
\hline \multirow{8}{*}{8} & \multirow{2}{*}{ Pari } & Manjoi & 95.00 & 0.87 \\
\hline & & Buntong & 70.00 & 0.77 \\
\hline & \multirow{2}{*}{ Raia } & Kampung Tanjung & 40.00 & 1.25 \\
\hline & & Batu Gajah & 80.95 & 0.88 \\
\hline & Kinta & Ipoh & 75.00 & 0.81 \\
\hline & Kampar & KM 34 & 80.95 & 0.84 \\
\hline & I anoat & Kajang & 35.00 & 1.24 \\
\hline & Langat & Dengkil & 100.00 & 0.90 \\
\hline \multirow{14}{*}{9} & Kulim & CH 14390 & 66.67 & 0.91 \\
\hline & & CH 3014 & 16.67 & 0.67 \\
\hline & & Average for All Data & 65.64 & 0.93 \\
\hline & \multirow{2}{*}{ Pari } & Manjoi & 90.00 & 0.93 \\
\hline & & Buntong & 100.00 & 0.88 \\
\hline & \multirow{2}{*}{ Raia } & Kampung Tanjung & 25.00 & 1.31 \\
\hline & & Batu Gajah & 95.24 & 1.03 \\
\hline & Kinta & Ipoh & 95.00 & 0.91 \\
\hline & Kampar & KM 34 & 100.00 & 0.97 \\
\hline & \multirow{2}{*}{ Langat } & Kajang & 20.00 & 1.40 \\
\hline & & Dengkil & 66.67 & 1.11 \\
\hline & \multirow{3}{*}{ Kulim } & CH 14390 & 100.00 & 0.94 \\
\hline & & CH 3014 & 33.33 & 0.71 \\
\hline & & Average for All Data & 71.78 & 1.03 \\
\hline
\end{tabular}

Note: Discrepancy Ratio $=Q_{\text {Computed }} / Q_{\text {Measured }}$.

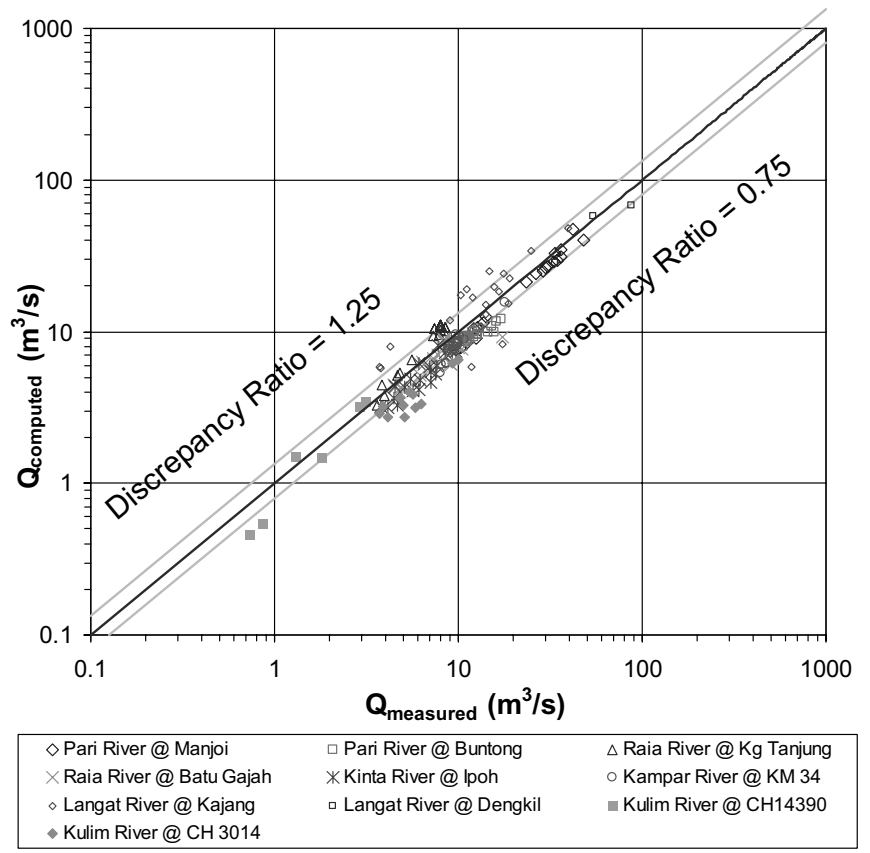

Figure 21 Comparison between measured and predicted $Q$ by equation 8 .

\section{Conclusions}

Applications of Manning $n$ values from the existing equations result in the computed discharges overpredicted the measured discharges. Attempts were then made to derive new equations for computing Manning $n$ for application to the moderate-size and sand-bed streams in Malaysia based on 168 data collected from

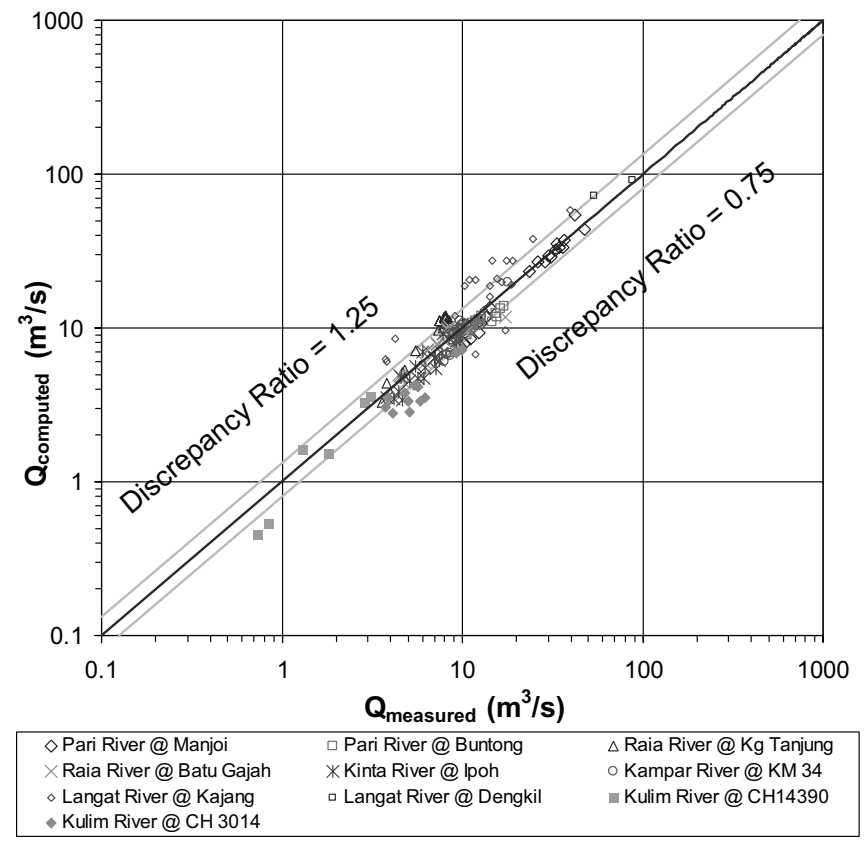

Figure 22 Comparison between measured and predicted $Q$ by equation 9 .

Kinta, Langat and Kulim Rivers. The resulting Equations 8 and 9 have an error less than $10 \%$ in predicting flow discharge for all the measured data.

\section{Acknowledgements}

The research study is funded by Department of Irrigation and Drainage Malaysia (JPS (PP)/SG/2/2000). The authors gratefully acknowledge Prof. Pierre Y. Julien (Colorado State University, USA), Prof. Willi H. Hager (ETH Zurich, Switzerland) and the reviewers for their comments on the manuscript.

\section{Notation}

$B=$ width of water surface (m)

$d=$ sediment size $(\mathrm{mm})$

$d_{i}=$ Size of particle intermediate axis for which $\mathrm{i} \%$ of sample of bed material is finer

$n=$ Manning's roughness coefficient

$Q=$ Discharge $\left(\mathrm{m}^{3} / \mathrm{s}\right)$

$T_{b}=$ Bed load $(\mathrm{kg} / \mathrm{s})$

$T_{s}=$ Suspended load $(\mathrm{kg} / \mathrm{s})$

$T_{j}=$ Total bed material load $(\mathrm{kg} / \mathrm{s})$

$R=$ Hydraulic radius $(\mathrm{m})$

$R^{2}=$ Regression coefficient

$S_{o}=$ Water-surface slope

$y_{o}=$ average flow depth $(\mathrm{m})$

\section{References}

1. Ab. Ghani, A., Zakaria, N.A., Abdullah, R., Chang, C.K., SinnaKaudan, S.K. and Mohd SideK, L. (2003). 
River Sediment Data Collection and Analysis Study, Contract Research No. JPS (PP)/SG/2/2000, Department of Irrigation and Drainage, Malaysia, Kuala Lumpur.

2. Abdul Ghaffar, A.B. (2003). Factors Affecting Values of Manning's Flow Resistance Coefficient. MSc. Thesis. Penang: Universiti Sains Malaysia.

3. ARIfFIn, J. (2004). Development of Sediment Transport Models for Rivers in Malaysia Using Regression Analysis and Artificial Neural Network, PhD. Thesis, Penang: Universiti Sains Malaysia.

4. BARNES, H.H. (1976). Roughness Characteristics of Natural Channels. http://www.engr.utk.edu/hydraulics/open channels/index.html.

5. BRAY, D.I. (1979). "Estimating Average Velocity in Gravelbed Rivers." Journal Hydraulic Division, ASCE, 105(HY9), 1103-1122.

6. BRusChIN, J. (1985). "Discussion on Brownlie (1983): Flow Depth in Sand-bed Channels." Journal of Hydraulic Engineering, ASCE, 111, 736-739.

7. Chang, C.K. (2006). Sediment Transport in Kulim River, Kedah, MSc. Thesis, Penang: Universiti Sains Malaysia.

8. Chow, V.T. (1959). Open Channel Hydraulics. Mc-GrawHill, Singapore.

9. Department of Irrigation and Drainage Malaysia (1976). River Discharge Measurement by Current Meter - Hydrological Procedure No. 15.

10. Department of Irrigation and Drainage Malaysia (1977). The Determination of Suspended Sediment Discharge Hydrological Procedure No. 19.

11. Dooge, J.C.I. (1991). The Manning Formula in Context - Channel Flow Resistance: Centennial of Manning's Formula. Water Resource Publications, Colorado, 136-185.

12. Edwards, T. K. and Glysson, G. D. (1999). Field Methods for Measurement of Fluvial Sediment. U.S. Geological Survey Techniques of Water-Resources Investigations, Chapter C2.

13. FISRWG - Federal Interagency Stream Restoration Working Group (2001). Stream Corridor Restoration: Principles, Processes, and Practices. Portland: Federal Interagency Stream Restoration Working Group (15 Federal agencies of the US Government).

14. GRAF, W.H. (1998). Fluvial Hydraulics - Flow and Transport Processes in Channels of Simple Geometry. John Wiley \& Sons, England.

15. Julien, P.Y. (2002). River Mechanics. Cambridge: Cambridge University Press UK.

16. Julien, P. Y., KlaAssen, G. J., Ten Brinke, W. B. M. and Wilbers, A. W. E. (2002). "Case Study: Bed Resistance of Rhine River during 1998 Flood." Journal of Hydraulic Engineering, ASCE, 128(12), 1042-1050.
17. Julien, P. Y., Ab. Ghani, A., Zakaria, N. A., Abdullah, R., Chang, C. K., RAMLI, R., Yusof, M. F., AbDul ManaP, A. and Dinor, J. (2006). Design Option Of The Flood Mitigation Plan of Sg. Muda, Sungai Muda, Kedah, Contract Research No. JPS(PP)/TB/2/06, Department of Irrigation and Drainage, Malaysia, Kuala Lumpur.

18. KARIM, F. (1995). "Bed Configuration and Hydraulic Resistance in Alluvial-Channel Flows." Journal of Hydraulic Engineering, ASCE, 121, No. 1, 15-25.

19. LANG, S., LAdSOn, T. and AndERson, B. (2004). "A Review of Empirical Equations for Estimating Stream Roughness and their Application to Four Streams in Victoria," Australian Journal of Water Resources, 8(1), 69-82.

20. Lagasse, P.F., Schall, J.D. and Richardson, E.V. (2001). Stream Stability At Highway Structures, US Department of Transportation, Federal Highway Administration. Publication No. FHWA NHI 01-002 (Hydraulic Engineering Circular No. 20), 3rd Edition.

21. Limerinos, J. T. (1970). Determination of the Manning Coefficient for Measured Bed Roughness in Natural Channels. Water Supply paper 1898-B, U.S.Geological Survey, Washington D.C.

22. Meyer-Peter, E. and Muller, R. (1948). Formulas for Bed-load Transport. Proceed. Third Meeting of IAHR, Stockholm, Sweden, 39-64.

23. RAHMEYER, W. (2007). Flow Resistance for Utah FloodPlains.

24. RAudKIVI, A.J. (1993). Sedimentation - Exclusion and Removal of Sediment from Diverted Water. Hydraulic Structures Design Manual No. 6, IAHR

25. Richardson, E V., Simons, D.B. and Lagasse, P. F. (2001). River Engineering for Highway Encroachments - Highways in The River Enviroment, US Department of Transportation, Federal Highway Administration. Publication No. FHWA NHI 01-004 (Hydraulic Design Series Number 6).

26. STRICKLER, A. (1923). Beitrage zur frage der geschwindigkeitsformel und der rauhigkeitszahlen fuer stroeme kanaele und geschlossene leitungen. Mitteilungen des eidgenossischen Amtes fuer Wasserwirtschaft 16. Bern, Switzerland.

27. United States Army Corps of Engineers. (1995). Sedimentation Investigations of Rivers and Reservoirs. USACE Engineering and Design Manual. Publication No. EM 1110-2-4000.

28. YEN, B.C. (2002). Open Channel Flow Resistance. Journal of Hydraulic Engineering ASCE, 128(1), 1-20.

29. YUQIAN, L. (1989). Manual on Operational Methods for the Measurement of Sediment Transport. World Meteorological Organisation - Operational Hydrology Report No. 29. 